\title{
LEVEL II SCOUR ANALYSIS FOR BRIDGE 32 (BURKTH00440032) on TOWN HIGHWAY 44, crossing ROUNDY BROOK, BURKE, VERMONT
}

Open-File Report 98-554

Prepared in cooperation with

VERMONT AGENCY OF TRANSPORTATION

and

FEDERAL HIGHWAY ADMINISTRATION

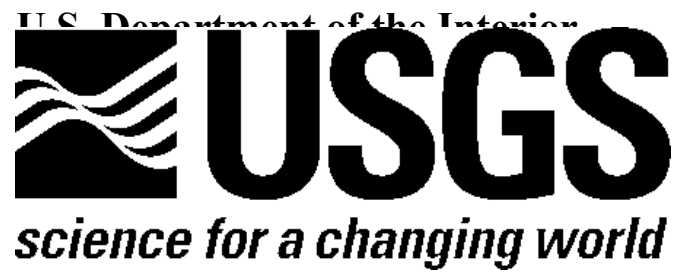




\section{LEVEL II SCOUR ANALYSIS FOR BRIDGE 32 (BURKTH00440032) on TOWN HIGHWAY 44, crossing ROUNDY BROOK, BURKE, VERMONT}

By MICHELLE M. SERRA AND ERICK M. BOEHMLER

U.S. Geological Survey Open-File Report 98-554

Prepared in cooperation with

VERMONT AGENCY OF TRANSPORTATION

and

FEDERAL HIGHWAY ADMINISTRATION 


\title{
U.S. DEPARTMENT OF THE INTERIOR BRUCE BABBITT, Secretary
}

\author{
U.S. GEOLOGICAL SURVEY
}

Thomas J. Casadevall, Acting Director

For additional information write to:

District Chief

U.S. Geological Survey 361 Commerce Way

Pembroke, NH 03275-3718
Copies of this report may be purchased from:

U.S. Geological Survey

Branch of Information Services

Open-File Reports Unit

Box 25286

Denver, CO 80225-0286 


\section{CONTENTS}

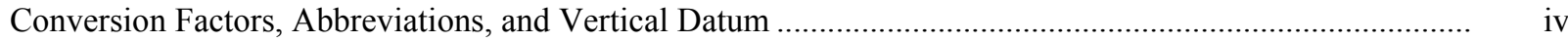

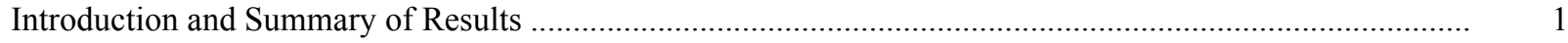

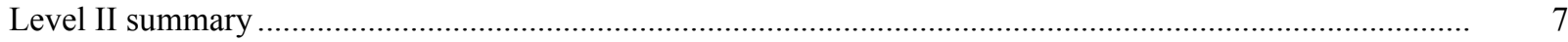

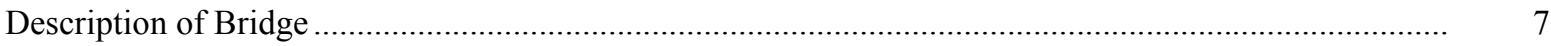

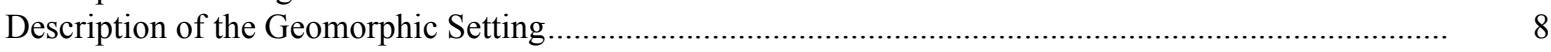

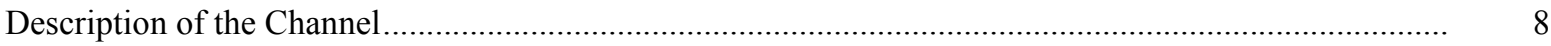

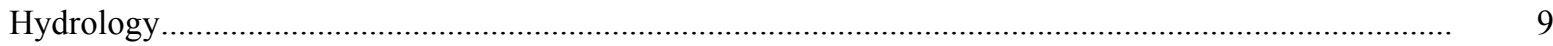

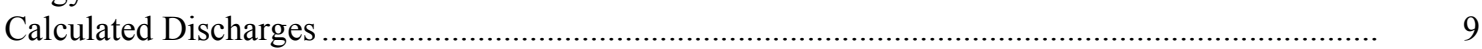

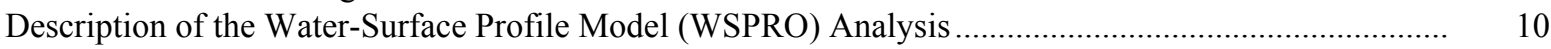

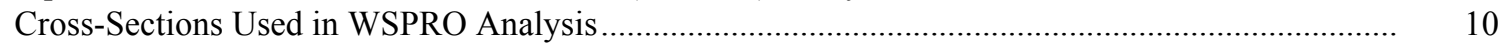

Data and Assumptions Used in WSPRO Model ........................................................................ 11

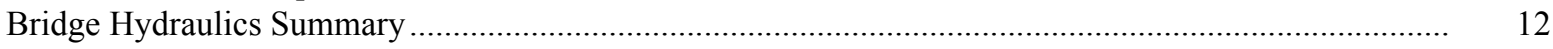

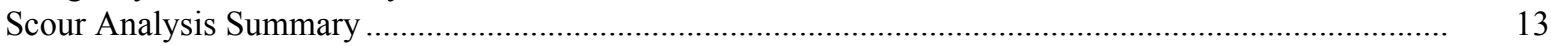

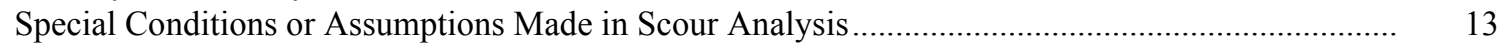

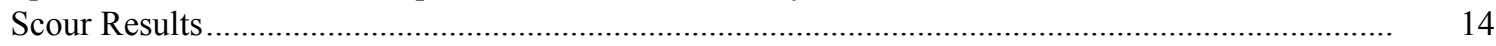

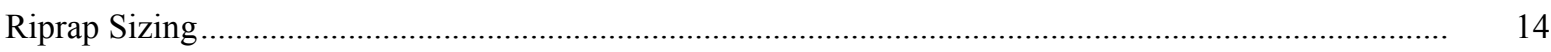

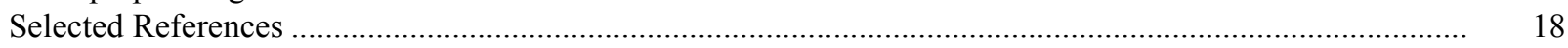

Appendices:

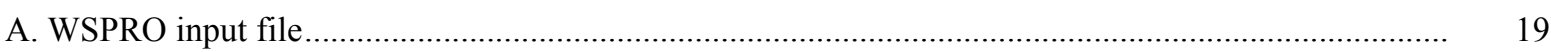

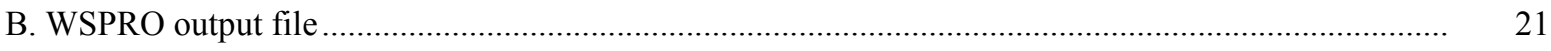

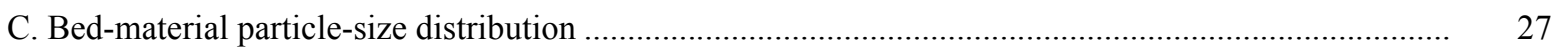

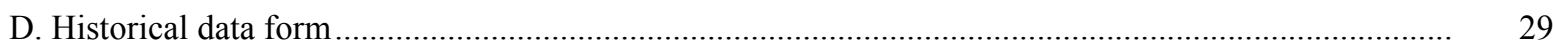

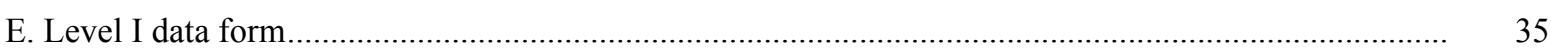

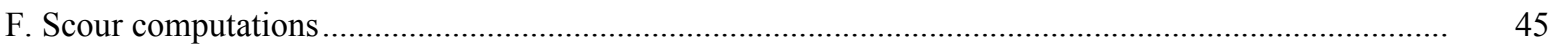

\section{FIGURES}

1. Map showing location of study area on USGS 1:24,000 scale map

2. Map showing location of study area on Vermont Agency of Transportation town highway map

3. Structure BURKTH00440032 viewed from upstream (August 8, 1995) ...

4. Downstream channel viewed from structure (August 8, 1995).....

5. Upstream channel viewed from structure BURKTH00440032 (August 8, 1995)

6. Structure BURKTH00440032 viewed from downstream (August 8, 1995).

7. Water-surface profiles for the 100- and 500-year discharges at structure

BURKTH00440032 on Town Highway 44, crossing Roundy Brook,

Burke, Vermont.

8. Scour elevations for the 100- and 500-year discharges at structure

BURKTH00440032 on Town Highway 44, crossing Roundy Brook,

Burke, Vermont.

\section{TABLES}

1. Remaining footing/pile depth at abutments for the 100-year discharge at structure

BURKTH00440032 on Town Highway 44, crossing Roundy Brook,

Burke, Vermont.

2. Remaining footing/pile depth at abutments for the 500-year discharge at structure

BURKTH00440032 on Town Highway 44, crossing Roundy Brook,

Burke, Vermont. 


\begin{tabular}{|c|c|c|}
\hline Multiply & By & To obtain \\
\hline \multicolumn{3}{|c|}{ Length } \\
\hline inch (in.) & 25.4 & millimeter (mm) \\
\hline foot $(\mathrm{ft})$ & 0.3048 & meter $(\mathrm{m})$ \\
\hline mile (mi) & 1.609 & kilometer (km) \\
\hline \multicolumn{3}{|c|}{ Slope } \\
\hline foot per mile ( $\mathrm{ft} / \mathrm{mi})$ & 0.1894 & meter per kilometer $(\mathrm{m} / \mathrm{km})$ \\
\hline \multicolumn{3}{|c|}{ Area } \\
\hline square mile $\left(\mathrm{mi}^{2}\right)$ & 2.590 & square kilometer $\left(\mathrm{km}^{2}\right)$ \\
\hline \multicolumn{3}{|c|}{ Volume } \\
\hline cubic foot $\left(\mathrm{ft}^{3}\right)$ & $\begin{array}{l}0.02832 \\
\text { Velocity and Flow }\end{array}$ & cubic meter $\left(\mathrm{m}^{3}\right)$ \\
\hline foot per second (ft/s) & 0.3048 & meter per second $(\mathrm{m} / \mathrm{s})$ \\
\hline cubic foot per second $\left(\mathrm{ft}^{3} / \mathrm{s}\right)$ & 0.02832 & cubic meter per second $\left(\mathrm{m}^{3} / \mathrm{s}\right)$ \\
\hline $\begin{array}{l}\text { cubic foot per second per } \\
\text { square mile } \\
{\left[\left(\mathrm{ft}^{3} / \mathrm{s}\right) / \mathrm{mi}^{2}\right]}\end{array}$ & 0.01093 & $\begin{array}{l}\text { cubic meter per } \\
\text { second per square } \\
\text { kilometer }\left[\left(\mathrm{m}^{3} / \mathrm{s}\right) / \mathrm{km}^{2}\right]\end{array}$ \\
\hline
\end{tabular}

\section{OTHER ABBREVIATIONS}

\begin{tabular}{|c|c|c|c|}
\hline $\mathrm{BF}$ & bank full & LWW & left wingwall \\
\hline $\mathrm{cfs}$ & cubic feet per second & Max & maximum \\
\hline $\mathrm{D}_{50}$ & median diameter of bed material & $\mathrm{MC}$ & main channel \\
\hline DS & downstream & RAB & right abutment \\
\hline elev. & elevation & RABUT & face of right abutment \\
\hline $\mathrm{f} / \mathrm{p}$ & flood plain & $\mathrm{RB}$ & right bank \\
\hline $\mathrm{ft}^{2}$ & square feet & ROB & right overbank \\
\hline $\mathrm{ft} / \mathrm{ft}$ & feet per foot & RWW & right wingwall \\
\hline FEMA & Federal Emergency Management Agency & $\mathrm{TH}$ & town highway \\
\hline FHWA & Federal Highway Administration & UB & under bridge \\
\hline JCT & junction & US & upstream \\
\hline LAB & left abutment & USGS & United States Geological Survey \\
\hline LABUT & face of left abutment & VTAOT & Vermont Agency of Transportation \\
\hline LB & left bank & WSPRO & water-surface profile model \\
\hline LOB & left overbank & $\mathrm{yr}$ & year \\
\hline
\end{tabular}

In this report, the words "right" and "left" refer to directions that would be reported by an observer facing downstream. Sea level: In this report, "sea level" refers to the National Geodetic Vertical Datum of 1929-- a geodetic datum derived from a general adjustment of the first-order level nets of the United States and Canada, formerly called Sea Level Datum of 1929.

In the appendices, the above abbreviations may be combined. For example, USLB would represent upstream left bank. 


\title{
LEVEL II SCOUR ANALYSIS FOR BRIDGE 32 (BURKTH00440032) ON TOWN HIGHWAY 44, CROSSING ROUNDY BROOK, BURKE, VERMONT
}

\author{
By Michelle M. Serra and Erick Boehmler
}

\section{INTRODUCTION AND SUMMARY OF RESULTS}

This report provides the results of a detailed Level II analysis of scour potential at structure BURKTH00440032 on Town Highway 44 crossing Roundy Brook, Burke, Vermont (figures 1-8). A Level II study is a basic engineering analysis of the site, including a quantitative analysis of stream stability and scour (FHWA, 1993). Results of a Level I scour investigation also are included in appendix $\mathrm{E}$ of this report. A Level I investigation provides a qualitative geomorphic characterization of the study site. Information on the bridge, gleaned from Vermont Agency of Transportation (VTAOT) files, was compiled prior to conducting Level I and Level II analyses and is found in appendix D.

The site is in the White Mountain section of the New England physiographic province in northeastern Vermont. The $9.24-\mathrm{mi}^{2}$ drainage area is in a predominantly rural and forested basin. In the vicinity of the study site, the surface cover is pasture on the upstream right bank and forested on the remaining banks.

In the study area, Roundy Brook has a sinuous channel with a slope of approximately 0.030 $\mathrm{ft} / \mathrm{ft}$, an average channel top width of $46 \mathrm{ft}$ and an average bank height of $8 \mathrm{ft}$. The channel bed material ranges from gravel to boulders under the bridge and downstream, and from silt to gravel in the upstream reach. The median grain size $\left(\mathrm{D}_{50}\right)$ is $28.7 \mathrm{~mm}(0.094 \mathrm{ft})$. The geomorphic assessment at the time of the Level I and Level II site visit on August 8, 1995, indicated that the reach was degraded. A crude downstream drop structure has kept the under-bridge bed elevation artificially high, while bed elevations in the upstream and downstream reaches are similar to one another and lower than under the bridge.

The Town Highway 44 crossing of Roundy Brook is a 43-ft-long, one-lane bridge consisting of one 39-foot steel-girder and floorbeam span (Vermont Agency of Transportation, written communication, March 24, 1995). The opening length of the structure parallel to the bridge face is $36.4 \mathrm{ft}$. The bridge is supported by vertical, concrete abutments with wingwalls. The channel is skewed zero degrees to the opening and the opening-skew-to-roadway is also zero degrees. 
No scour holes were noted at this site during the Level 1 assessment. Scour protection at this site consisted of type-2 (less than 36 inches diameter) stone fill on the downstream left and right wingwalls, the upstream right wingwall, and the downstream left bank. During the Level I assessment, the right abutment and downstream right wingwall footings were exposed up to $0.5 \mathrm{ft}$. Additional details describing conditions at the site are included in the Level II Summary and appendices D and E.

Scour depths and recommended rock rip-rap sizes were computed using the general guidelines described in Hydraulic Engineering Circular 18 (Richardson and Davis, 1995) for the 100- and 500-year discharges. Total scour at a highway crossing is comprised of three components: 1) long-term streambed degradation; 2) contraction scour (due to accelerated flow caused by a reduction in flow area at a bridge) and; 3 ) local scour (caused by accelerated flow around piers and abutments). Total scour is the sum of the three components. Equations are available to compute depths for contraction and local scour and a summary of the results of these computations follows.

Contraction scour for all modelled flows ranged from 2.4 to $3.4 \mathrm{ft}$. The worst-case contraction scour occurred at the 500-year discharge. Abutment scour ranged from 7.5 to $12.9 \mathrm{ft}$. The worst-case abutment scour occurred at the 500-year discharge. Additional information on scour depths and depths to armoring are included in the section titled "Scour Results". Scoured-streambed elevations, based on the calculated scour depths, are presented in tables 1 and 2. A cross-section of the scour computed at the bridge is presented in figure 8. Scour depths were calculated assuming an infinite depth of erosive material and a homogeneous particle-size distribution.

It is generally accepted that the Froehlich equation (abutment scour) gives "excessively conservative estimates of scour depths" (Richardson and Davis, 1995, p. 46). Usually, computed scour depths are evaluated in combination with other information including (but not limited to) historical performance during flood events, the geomorphic stability assessment, existing scour protection measures, and the results of the hydraulic analyses. Therefore, scour depths adopted by VTAOT may differ from the computed values documented herein. 


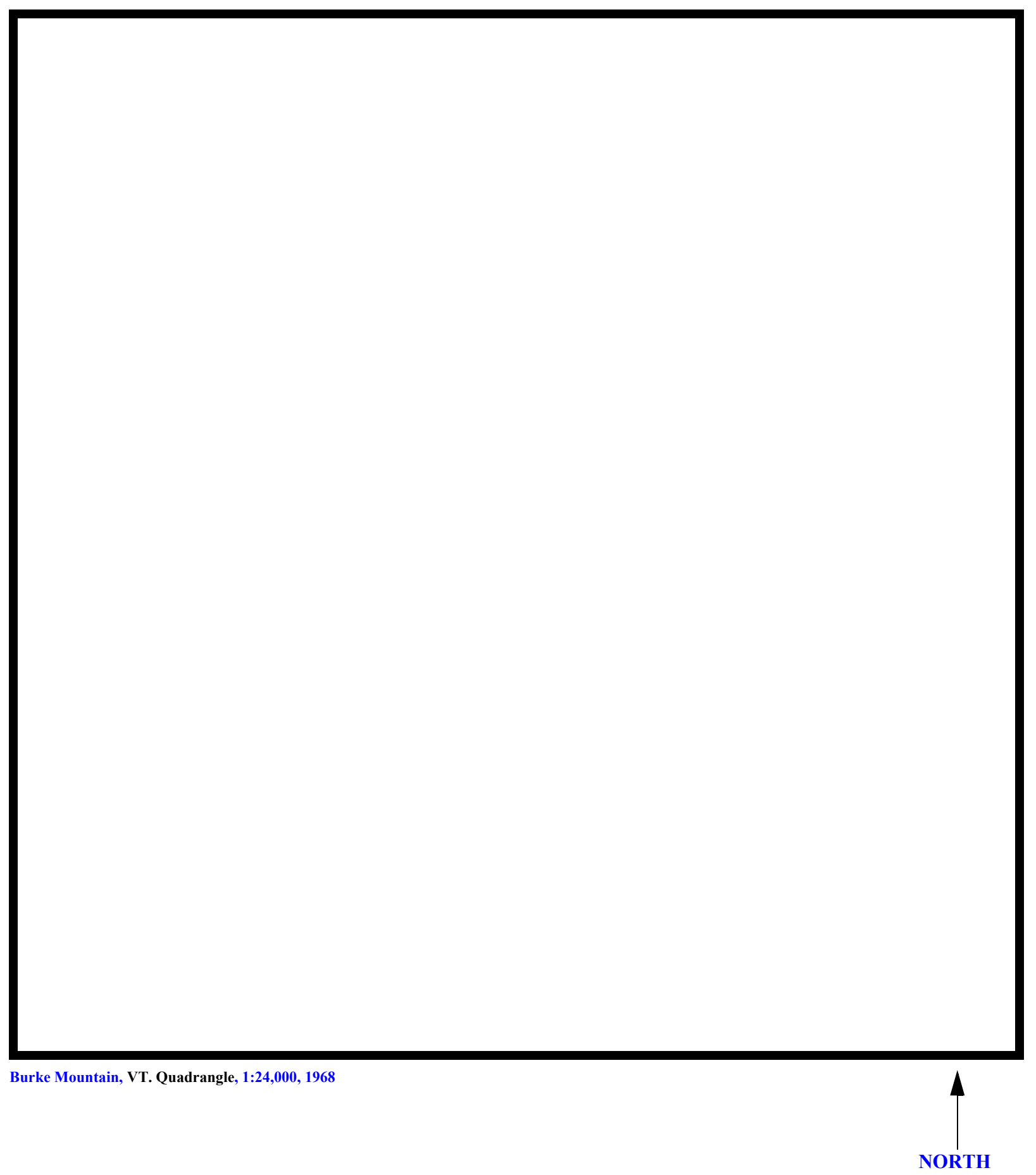

Figure 1. Location of study area on USGS 1:24,000 scale map. 
Figure 2. Location of study area on Vermont Agency of Transportation town highway map. 

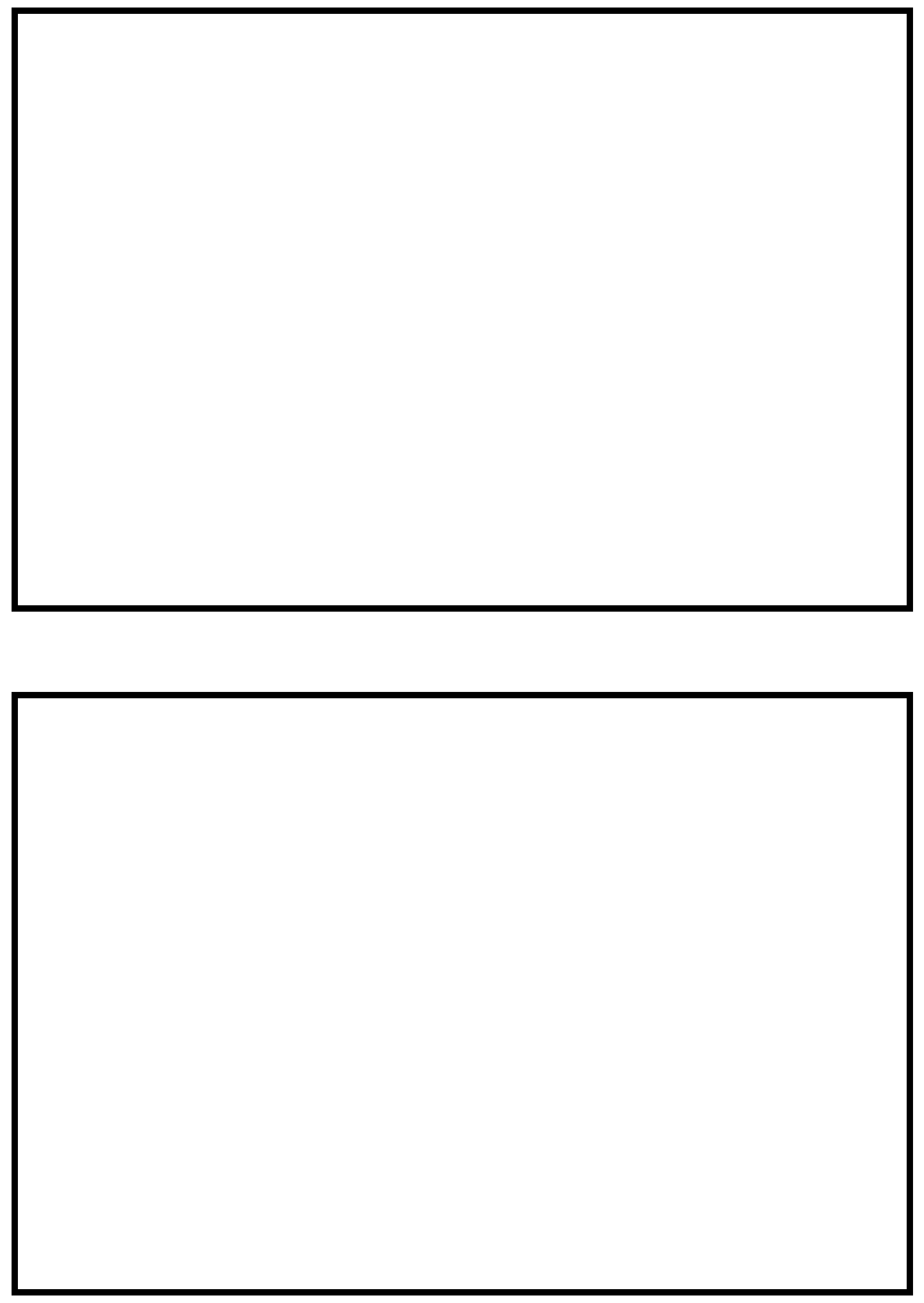

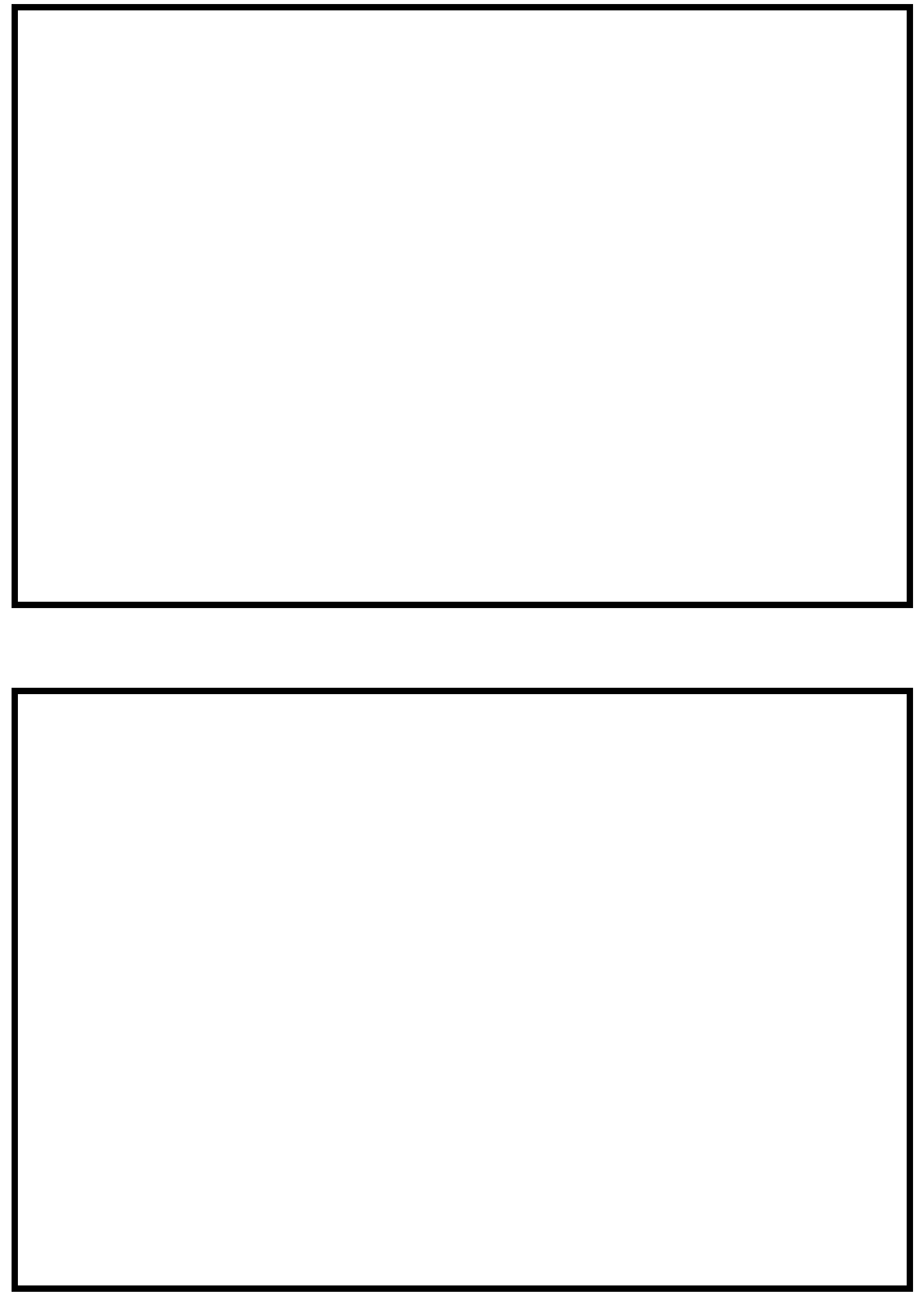


\section{LEVEL II SUMMARY}

\begin{tabular}{llllll} 
Structure Number & \multicolumn{2}{c}{ BURKTH00440032 } & Stream & \multicolumn{3}{c}{ Roundy Brook } \\
& Road & TH44 & District & 7
\end{tabular}

\section{Description of Bridge}

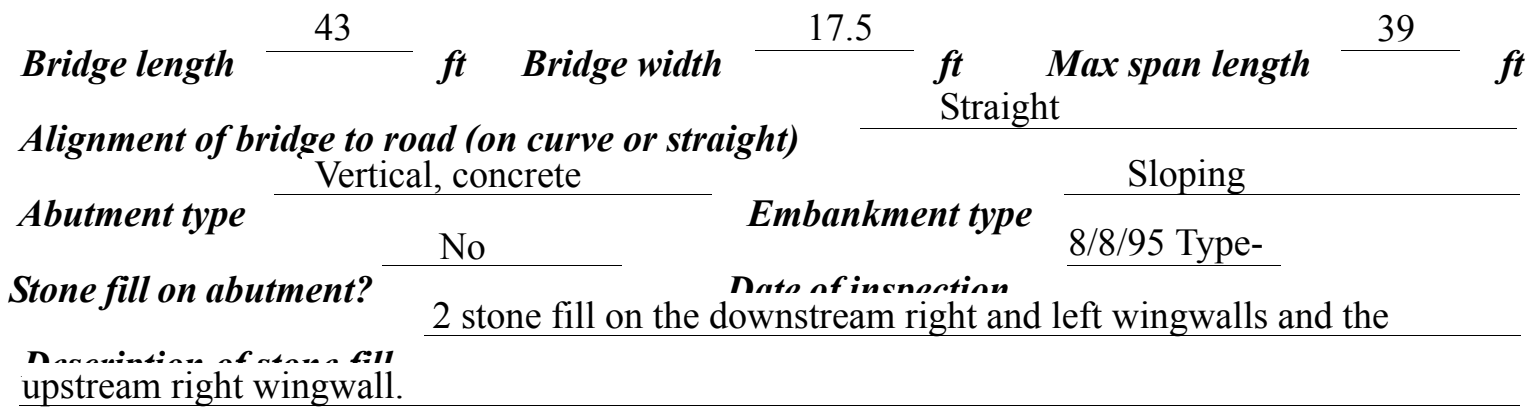

The abutments and wingwalls are concrete. The right abutment and the downstream right wingwall footings are exposed $0.5 \mathrm{ft}$.

\section{No}

Is bridge skewed to flood flow according to Yes ' survey?

Angle

There is a severe bend in the upstream reach where a cutbank has formed due to the impact of flow on the bank.

Debris accumulation on bridge at time of Level I or Level II site visit:

\begin{tabular}{|c|c|c|c|}
\hline & $\begin{array}{c}\text { Date of insnortion } \\
\quad 8 / 8 / 95 \\
\end{array}$ & $\begin{array}{l}\text { Percent of almunal } \\
\text { bloeked inortzontatly }\end{array}$ & $\begin{array}{l}\text { Percent of } 0 \\
\text { blocked verticatty }\end{array}$ \\
\hline Level I & $8 / 8 / 95$ & 0 & 0 \\
\hline $\begin{array}{l}\text { Level II } \\
\text { upstrean }\end{array}$ & \multicolumn{3}{|c|}{ Potential for debris is high due to the trees and vegetation on the } \\
\hline
\end{tabular}

None as of $8 / 8 / 95$.

Dosrriho any, foaturos noar ar at tho hridoo that mav, affort flow, (includo ahsorvation dato) 


\section{Description of the Geomorphic Setting}

General topography The channel is located in a moderate relief valley with little to no flood plains.

Geomorphic conditions at bridge site: downstream (DS), upstream (US)

Date of inspection $\quad 8 / 8 / 95$

DS left: $\quad$ Moderately sloped channel bank to mildly sloped overbank

DS right: $\quad$ Steep channel bank to moderately sloped overbank

US left: $\quad$ Steep channel bank to moderately sloped overbank

US right: $\quad$ Steep channel bank

\section{Description of the Channel}

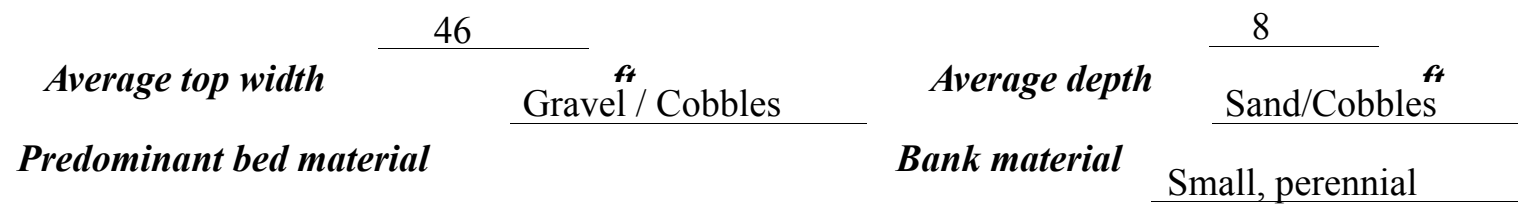

stream that is sinuous and degraded with semi-alluvial channel boundaries.

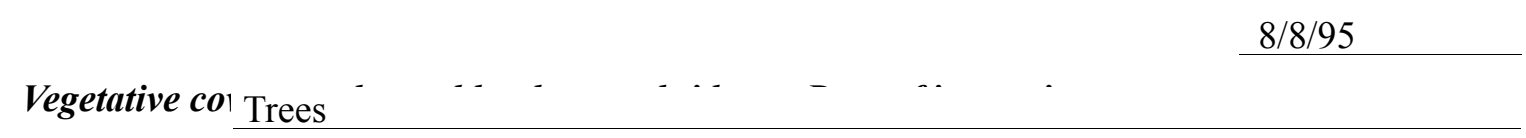

DS left: $\quad$ Trees

DS right: $\quad$ Trees

US left: $\quad$ Grass, trees, shrubs, and brush

US right: $\quad$ Yes

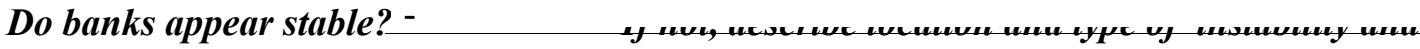

date of observatton.

Some trees, fallen into

the channel upstream of the bridge, have captured leaves and branches making the debris more Describe any obstructions in channel and date of observation.

dense, as observed on $8 / 8 / 95$ 


\title{
Hydrology
}

Drainage area $\quad \frac{9.24}{m^{2}}{ }^{2}$

Percentage of drainage area in physiographic provinces: (approximate)

Physiographic province/section

New England/White Mountain
Percent of drainage area 100

\begin{abstract}
Is drainage area considered rural or urban?
Rural None as of $8 / 8 / 95$. urbanization:
\end{abstract}

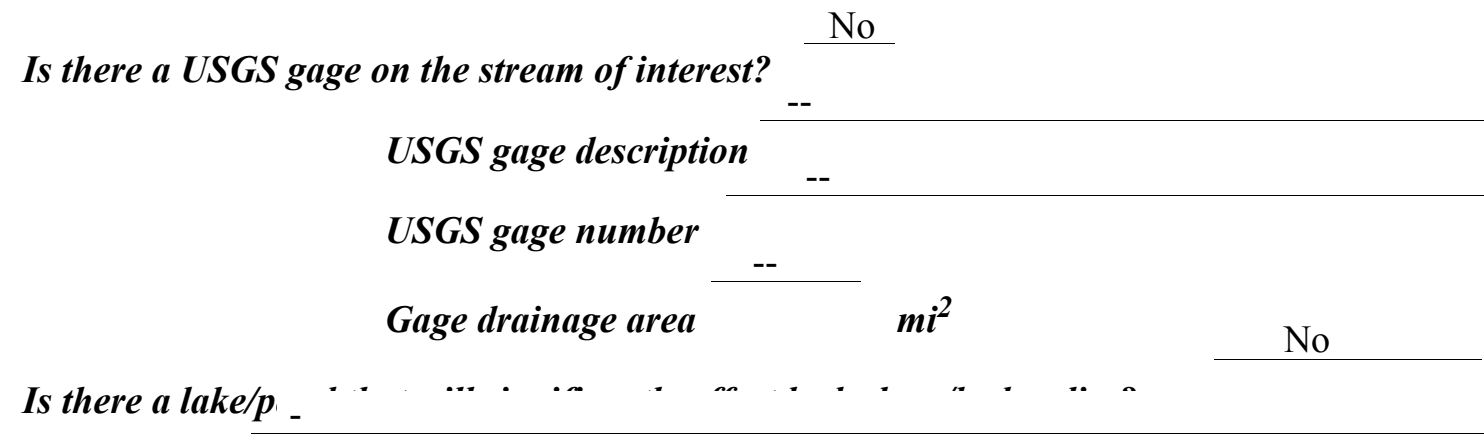

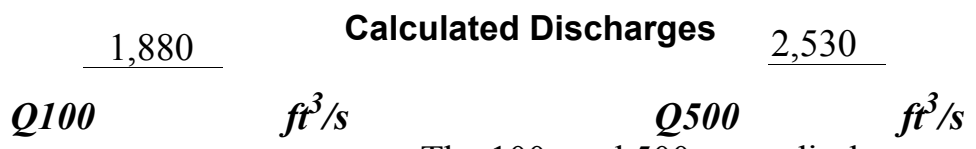

The 100- and 500- year discharges are based on a

drainage-area relationship [(9.24/8.1)exp 0.67] with discharge values from the Flood Insurance Study for the town of Burke, at the downstream limit of a detailed study of Roundy Brook (FEMA, 1979). These values were within a range defined by flood frequency curves derived from several empirical methods (Benson, 1962; Johnson and Tasker, 1974; FHWA, 1983; Potter, 1957a\&b; Talbot, 1887). Each curve (except the FEMA curve) was extended graphically to the 500-year event. 


\section{Description of the Water-Surface Profile Model (WSPRO) Analysis}

Datum for WSPRO analysis (USGS survey, sea level, VTAOT plans)

USGS survey

Datum tie between USGS survey and VTAOT plans

None

Description of reference marks used to determine USGS datum. $\quad$ RM1 is a chiseled X on

top of a concrete guard rail post above the US end of the LABUT (elev. $515.14 \mathrm{ft}$, arbitrary

survey datum). RM2 is a chiseled $\mathrm{X}$ on top of the concrete along the downstream right bridge

face just inside the guard-rail post (elev. $512.85 \mathrm{ft}$, arbitrary survey datum).

\section{Cross-Sections Used in WSPRO Analysis}

\begin{tabular}{|c|c|c|c|}
\hline${ }^{1}$ Cross-section & $\begin{array}{c}\text { Section } \\
\text { Reference } \\
\text { Distance } \\
\text { (SRD) in feet }\end{array}$ & $\begin{array}{c}{ }^{2} \text { Cross-section } \\
\text { development }\end{array}$ & Comments \\
\hline EXITX & -36 & 1 & Exit section \\
\hline FULLV & 0 & 2 & $\begin{array}{l}\text { Downstream Full-valley } \\
\text { section (Templated from } \\
\text { EXITX) }\end{array}$ \\
\hline BRIDG & 0 & 1 & Bridge section \\
\hline RDWAY & 10 & 1 & Road Grade section \\
\hline APPRO & 57 & 1 & Approach section \\
\hline
\end{tabular}

${ }^{1}$ For location of cross-sections see plan-view sketch included with Level I field form, Appendix E. For more detail on how cross-sections were developed see WSPRO input file. 


\section{Data and Assumptions Used in WSPRO Model}

Hydraulic analyses of the reach were done by use of the Federal Highway Administration's WSPRO step-backwater computer program (Shearman and others, 1986, and Shearman, 1990). The analyses reported herein reflect conditions existing at the site at the time of the study. Furthermore, in the development of the model it was necessary to assume no accumulation of debris or ice at the site. Results of the hydraulic model are presented in the Bridge Hydraulic Summary, appendix B, and figure 7.

Channel roughness factors (Manning's " $n$ ") used in the hydraulic model were estimated using field inspections at each cross section following the general guidelines described by Arcement and Schneider (1989). Final adjustments to the values were made during the modelling of the reach. Channel " $n$ " values for the reach ranged from 0.040 to 0.055 , and overbank " $n$ " values ranged from 0.040 to 0.070 .

Critical depth at the exit section (EXITX) was assumed as the starting water surface for the each modeled discharge. Normal depth was computed at critical depth for the 100-year discharge and below critical depth approximately $0.11 \mathrm{ft}$ for the 500 -year discharge by use of the slope-conveyance method outlined in the user's manual for WSPRO (Shearman, 1990). The slope used was $0.0300 \mathrm{ft} / \mathrm{ft}$, which was the 100-year discharge water-surface slope downstream of the bridge in the Flood Insurance Study for Burke, Vermont (FEMA, 1979).

The approach section (APPRO) was surveyed one bridge length upstream of the upstream face as recommended by Shearman and others (1986). This location provides a consistent method for determining scour variables.

For the 100- and 500-year discharges, WSPRO assumes critical depth at the bridge section. Supercritical models were developed for these discharges. After analyzing the supercritical and subcritical profiles for each discharge, it was assumed that the water-surface profile passes through critical depth within the bridge opening. Thus, the assumptions of critical depth at the bridge are satisfactory solutions. 


\section{Bridge Hydraulics Summary}

\begin{tabular}{llll} 
Average bridge embankment elevation & \multicolumn{2}{c}{512.6} \\
Average low steel elevation & 510.3 & $\boldsymbol{f t}$
\end{tabular}

100-year discharge $\quad 1,880 \quad \mathrm{ft}^{3} / \mathrm{s}$

Water-surface elevation in bridge opening $\quad 500.9 \quad f t$

Road overtopping? ___ No Discharge over road ___ - $\mathrm{ft}^{3} / \mathrm{s}$

Area of flow in bridge opening $\quad 159 \quad \boldsymbol{f t}^{2}$

Average velocity in bridge opening $11.8 \mathrm{ft} / \mathrm{s}$

Maximum WSPRO tube velocity at bridge $14.6 \mathrm{ft} / \mathrm{s}$

Water-surface elevation at Approach section with bridge 503.3

Water-surface elevation at Approach section without bridge

Amount of backwater caused by bridge $\quad 1.6 \quad$ it

501.7

500-year discharge $\quad 2,530 \quad \mathrm{ft}^{3} / \mathrm{s}$

Water-surface elevation in bridge opening $501.9 \mathrm{ft}$

Road overtopping? ___ No Discharge over road ___ _ $\quad \mathrm{ft}^{3} / \mathrm{s}$

Area of flow in bridge opening $\quad 193 \quad \mathrm{ft}^{2}$

Average velocity in bridge opening $13.1 \mathrm{ft} / \mathrm{s}$

Maximum WSPRO tube velocity at bridge 16.1 's

Water-surface elevation at Approach section with bridge 504.7

Water-surface elevation at Approach section without bridge $\quad 503.0$

Amount of backwater caused by bridge $\quad 1.7$.t

Incipient overtopping discharge ___ _ $\mathrm{ft}^{3} / \mathrm{s}$

Water-surface elevation in bridge opening $\quad-\quad t_{t}$

Area of flow in bridge opening _ _ _ $\mathrm{ft}^{2}$

Average velocity in bridge opening $\quad-\quad f t / s$

Maximum WSPRO tube velocity at bridge _ _ $\quad \mathrm{ft} / \mathrm{s}$

Water-surface elevation at Approach section with bridge

Water-surface elevation at Approach section without bridge

Amount of backwater caused by bridge _ _ _ it 


\section{Scour Analysis Summary}

\section{Special Conditions or Assumptions Made in Scour Analysis}

Scour depths were computed using the general guidelines described in Hydraulic Engineering Circular 18 (Richardson and Davis, 1995). Scour depths were calculated assuming an infinite depth of erosive material and a homogeneous particle-size distribution. The results of the scour analyses for the 100- and 500-year discharges are presented in tables 1 and 2 and the scour depths are shown graphically in figure 8.

Contraction scour for the 100- and 500-year discharges was computed by use of the Laursen clear-water contraction scour equation (Richardson and Davis, 1995, p. 32, equation 20). Variables for the Laursen clear-water contraction scour equation include the discharge through the bridge, the width of the channel at the bridge, and the median grain size of the channel bed material. The streambed armoring depth computed for the 100-year discharge suggests that armoring will not limit the depth of contraction scour.

Abutment scour for both discharges was computed by use of the Froehlich equation (Richardson and Davis, 1995, p. 48, equation 28). Variables for the Froehlich equation include the Froude number of the flow approaching the embankments, the length of the embankment blocking flow, and the depth of flow approaching the embankment less any roadway overtopping. 


\section{Scour Results}

\section{0-yr discharge 500-yr discharge}

Contraction scour:

(Scour depths in feet)

Main channel

Live-bed scour

Clear-water scour

Depth to armoring

Left overbank

Right overbank

Local scour:

Abutment scour

\subsection{8 .8}

$--\quad 9.2$

12.9

Left abutment

Right abutment

Pier scour

Pier 1

Pier 2
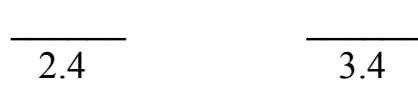

$29.3^{-}$

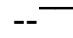

$--$

$\mathrm{N} / \mathrm{A}^{-}$

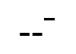

overtopping discharge

Incipient 


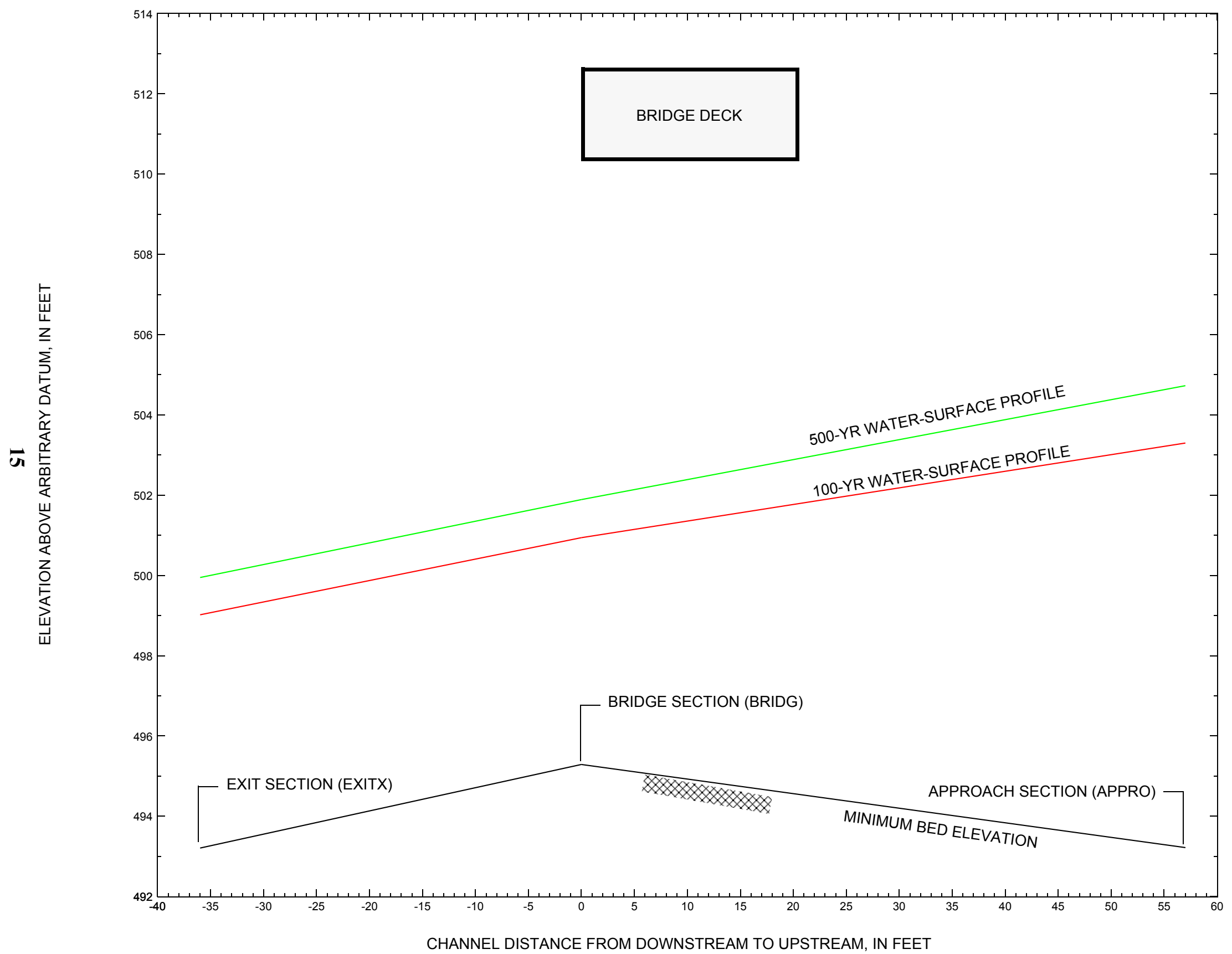

Figure 7. Water-surface profiles for the 100- and 500-year discharges at structure BURKTH00440032 on Town Highway 44, crossing Roundy Brook, Burke, Vermont. 


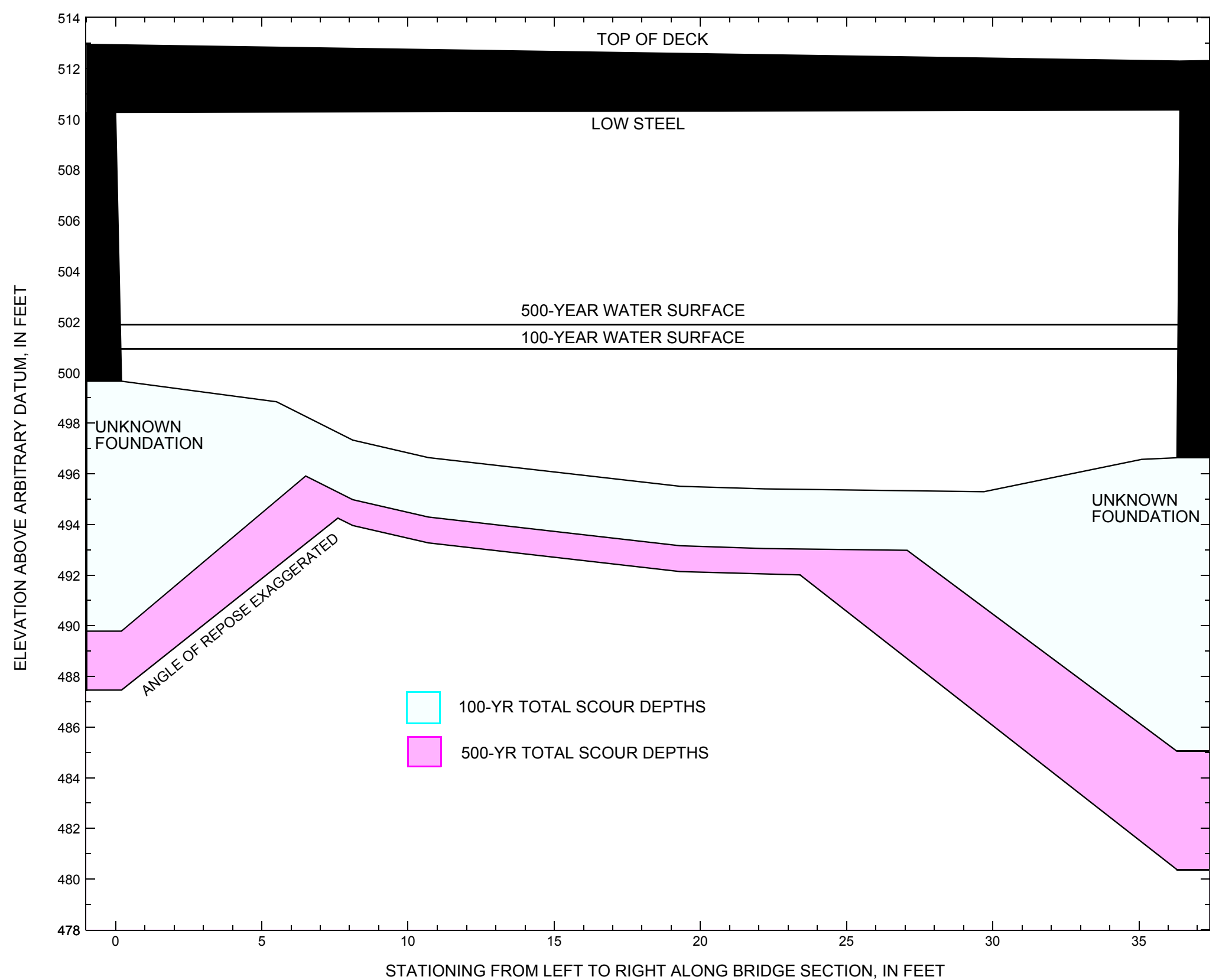

Figure 8. Scour elevations for the 100-year and 500-year discharges at structure BURKTH00440032 on Town Highway 44, crossing Roundy Brook, Burke, Vermont. 
Table 1. Remaining footing/pile depth at abutments for the 100-year discharge at structure BURKTH00440032 on Town Highway 44, crossing Roundy Brook, Burke, Vermont.

[VTAOT, Vermont Agency of Transportation; --, no data]

\begin{tabular}{|c|c|c|c|c|c|c|c|c|c|c|c|}
\hline Description & Station $^{1}$ & $\begin{array}{l}\text { VTAOT } \\
\text { minimum } \\
\text { low-chord } \\
\text { elevation } \\
\text { (feet) }\end{array}$ & $\begin{array}{l}\text { Surveyed } \\
\text { minimum } \\
\text { low-chord } \\
\text { elevation }{ }^{2} \\
\text { (feet) }\end{array}$ & $\begin{array}{c}\text { Bottom of } \\
\text { footing/pile } \\
\text { elevation }{ }^{2} \\
\text { (feet) }\end{array}$ & $\begin{array}{c}\text { Channel } \\
\text { elevation at } \\
\text { abutment/ } \\
\text { pier }^{2} \\
\text { (feet) }\end{array}$ & $\begin{array}{l}\text { Contraction } \\
\text { scour depth } \\
\text { (feet) }\end{array}$ & $\begin{array}{l}\text { Abutment } \\
\text { scour } \\
\text { depth } \\
\text { (feet) }\end{array}$ & $\begin{array}{l}\text { Pier } \\
\text { scour } \\
\text { depth } \\
\text { (feet) }\end{array}$ & $\begin{array}{l}\text { Depth of } \\
\text { total scour } \\
\text { (feet) }\end{array}$ & $\begin{array}{c}\text { Elevation of } \\
\text { scour }^{2} \\
\text { (feet) }\end{array}$ & $\begin{array}{c}\text { Remaining } \\
\text { footing/pile } \\
\text { depth } \\
\text { (feet) }\end{array}$ \\
\hline \multicolumn{12}{|c|}{100 -year discharge is 1,880 cubic-feet per second } \\
\hline Left abutment & 0.0 & -- & 510.3 & -- & 499.6 & 2.4 & 7.5 & -- & 9.9 & 489.8 & -- \\
\hline Right abutment & 36.4 & -- & 510.4 & -- & 496.6 & 2.4 & 9.2 & -- & 11.6 & 485.0 & -- \\
\hline
\end{tabular}

1.Measured along the face of the most constricting side of the bridge.

2.Arbitrary datum for this study.

Table 2. Remaining footing/pile depth at abutments for the 500-year discharge at structure BURKTH00440032 on Town Highway 44, crossing Roundy Brook, Burke, Vermont.

[VTAOT, Vermont Agency of Transportation; --, no data]

\begin{tabular}{|c|c|c|c|c|c|c|c|c|c|c|c|}
\hline Description & Station $^{1}$ & $\begin{array}{l}\text { VTAOT } \\
\text { minimum } \\
\text { low-chord } \\
\text { elevation } \\
\text { (feet) }\end{array}$ & $\begin{array}{c}\text { Surveyed } \\
\text { minimum } \\
\text { low-chord } \\
\text { elevation } \\
\text { (feet) }\end{array}$ & $\begin{array}{c}\text { Bottom of } \\
\text { footing/pile } \\
\text { elevation } \\
\text { (feet) }\end{array}$ & $\begin{array}{c}\text { Channel } \\
\text { elevation at } \\
\text { abutment/ } \\
\text { pier }^{2} \\
\text { (feet) }\end{array}$ & $\begin{array}{l}\text { Contraction } \\
\text { scour depth } \\
\text { (feet) }\end{array}$ & $\begin{array}{c}\text { Abutment } \\
\text { scour } \\
\text { depth } \\
\text { (feet) }\end{array}$ & $\begin{array}{l}\text { Pier } \\
\text { scour } \\
\text { depth } \\
\text { (feet) }\end{array}$ & $\begin{array}{l}\text { Depth of } \\
\text { total scour } \\
\text { (feet) }\end{array}$ & $\begin{array}{c}\text { Elevation of } \\
\text { scour }^{2} \\
\text { (feet) }\end{array}$ & $\begin{array}{c}\text { Remaining } \\
\text { footing/pile } \\
\text { depth } \\
\text { (feet) }\end{array}$ \\
\hline \multicolumn{12}{|c|}{500 -year discharge is 2,530 cubic-feet per second } \\
\hline Left abutment & 0.0 & -- & 510.3 & -- & 499.6 & 3.4 & 8.8 & -- & 12.2 & 487.5 & -- \\
\hline Right abutment & 36.4 & -- & 510.4 & -- & 496.6 & 3.4 & 12.9 & -- & 16.3 & 480.3 & -- \\
\hline
\end{tabular}

1.Measured along the face of the most constricting side of the bridge.

2.Arbitrary datum for this study. 


\section{SELECTED REFERENCES}

Arcement, G.J., Jr., and Schneider, V.R., 1989, Guide for selecting Manning's roughness coefficients for natural channels and flood plains:

U.S. Geological Survey Water-Supply Paper 2339, 38 p.

Barnes, H.H., Jr., 1967, Roughness characteristics of natural channels: U.S. Geological Survey Water-Supply Paper 1849,213 p.

Benson, M. A., 1962, Factors Influencing the Occurrence of Floods in a Humid Region of Diverse Terrain: U.S. Geological Survey WaterSupply Paper 1580-B, 64 p.

Brown, S.A. and Clyde, E.S., 1989, Design of riprap revetment: Federal Highway Administration Hydraulic Engineering Circular No. 11, Publication FHWA-IP-89-016, 156 p.

Federal Emergency Management Agency, 1979, Flood Insurance Study, Town of Burke, Caledonia County, Vermont: Washington, D.C., December 1979.

Federal Highway Administration, 1983, Runoff estimates for small watersheds and development of sound design: Federal Highway Administration Report FHWA-RD-77-158.

Federal Highway Administration, 1993, Stream Stability and Scour at Highway Bridges: Participant Workbook: Federal Highway Administration Report FHWA-HI-91-011.

Froehlich, D.C., 1989, Local scour at bridge abutments in Ports, M.A., ed., Hydraulic Engineering--Proceedings of the 1989 National Conference on Hydraulic Engineering: New York, American Society of Civil Engineers, p. 13-18.

Hayes, D.C.,1993, Site selection and collection of bridge-scour data in Delaware, Maryland, and Virginia: U.S. Geological Survey WaterResources Investigation Report 93-4017, 23 p.

Interagency Advisory Committee on Water Data, 1982, Guidelines for determining flood flow frequency: U.S. Geological Survey, Bulletin 17B of the Hydrology Subcommittee, 190 p.

Johnson, C.G. and Tasker, G.D.,1974, Progress report on flood magnitude and frequency of Vermont streams: U.S. Geological Survey OpenFile Report 74-130, 37 p.

Lagasse, P.F., Schall, J.D., Johnson, F., Richardson, E.V., Chang, F., 1995, Stream Stability at Highway Structures: Federal Highway Administration Hydraulic Engineering Circular No. 20, Publication FHWA-IP-90-014, 144 p.

Laursen, E.M., 1960, Scour at bridge crossings: Journal of the Hydraulics Division, American Society of Civil Engineers, v. 86, no. HY2, p. 39-53.

Potter, W. D., 1957a, Peak rates of runoff in the Adirondack, White Mountains, and Maine woods area, Bureau of Public Roads

Potter, W. D., 1957b, Peak rates of runoff in the New England Hill and Lowland area, Bureau of Public Roads

Richardson, E.V. and Davis, S.R., 1995, Evaluating scour at bridges: Federal Highway Administration Hydraulic Engineering Circular No. 18, Publication FHWA-IP-90-017, 204 p.

Richardson, E.V., Simons, D.B., and Julien, P.Y., 1990, Highways in the river environment: Federal Highway Administration Publication FHWA-HI-90-016.

Ritter, D.F., 1984, Process Geomorphology: W.C. Brown Co., Debuque, Iowa, 603 p.

Shearman, J.O., 1990, User's manual for WSPRO--a computer model for water surface profile computations: Federal Highway Administration Publication FHWA-IP-89-027, 187 p.

Shearman, J.O., Kirby, W.H., Schneider, V.R., and Flippo, H.N., 1986, Bridge waterways analysis model; research report: Federal Highway Administration Publication FHWA-RD-86-108, 112 p.

Talbot, A.N., 1887, The determination of water-way for bridges and culverts.

U.S. Geological Survey, 1988, Burke Mountain, Vermont 7.5 Minute Series quadrangle map: U.S. Geological Survey Topographic Maps, Scale 1:24,000. 


\section{APPENDIX A: \\ WSPRO INPUT FILE}




\section{WSPRO INPUT FILE}

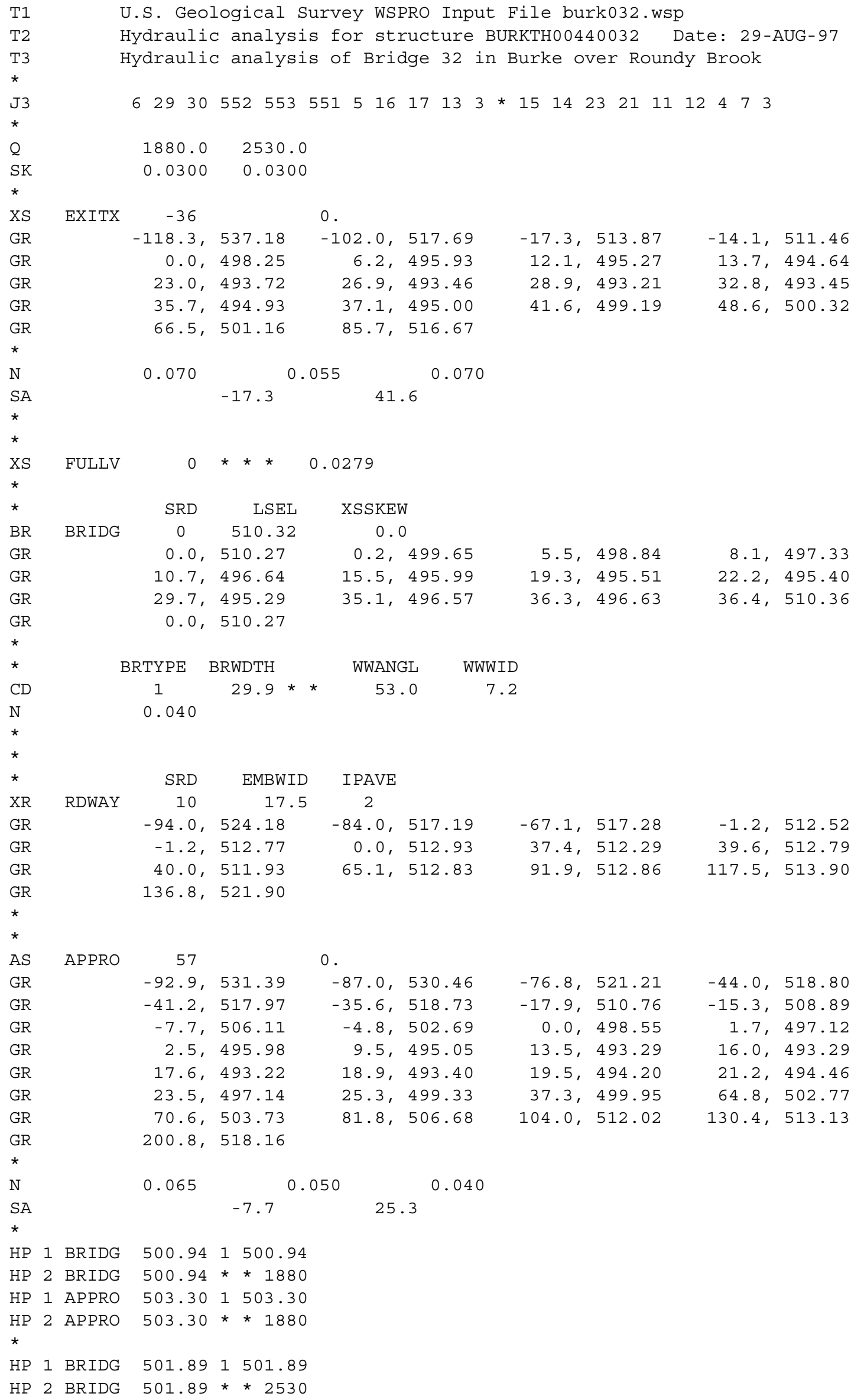




\section{APPENDIX B: \\ WSPRO OUTPUT FILE}


WSPRO OUTPUT FILE

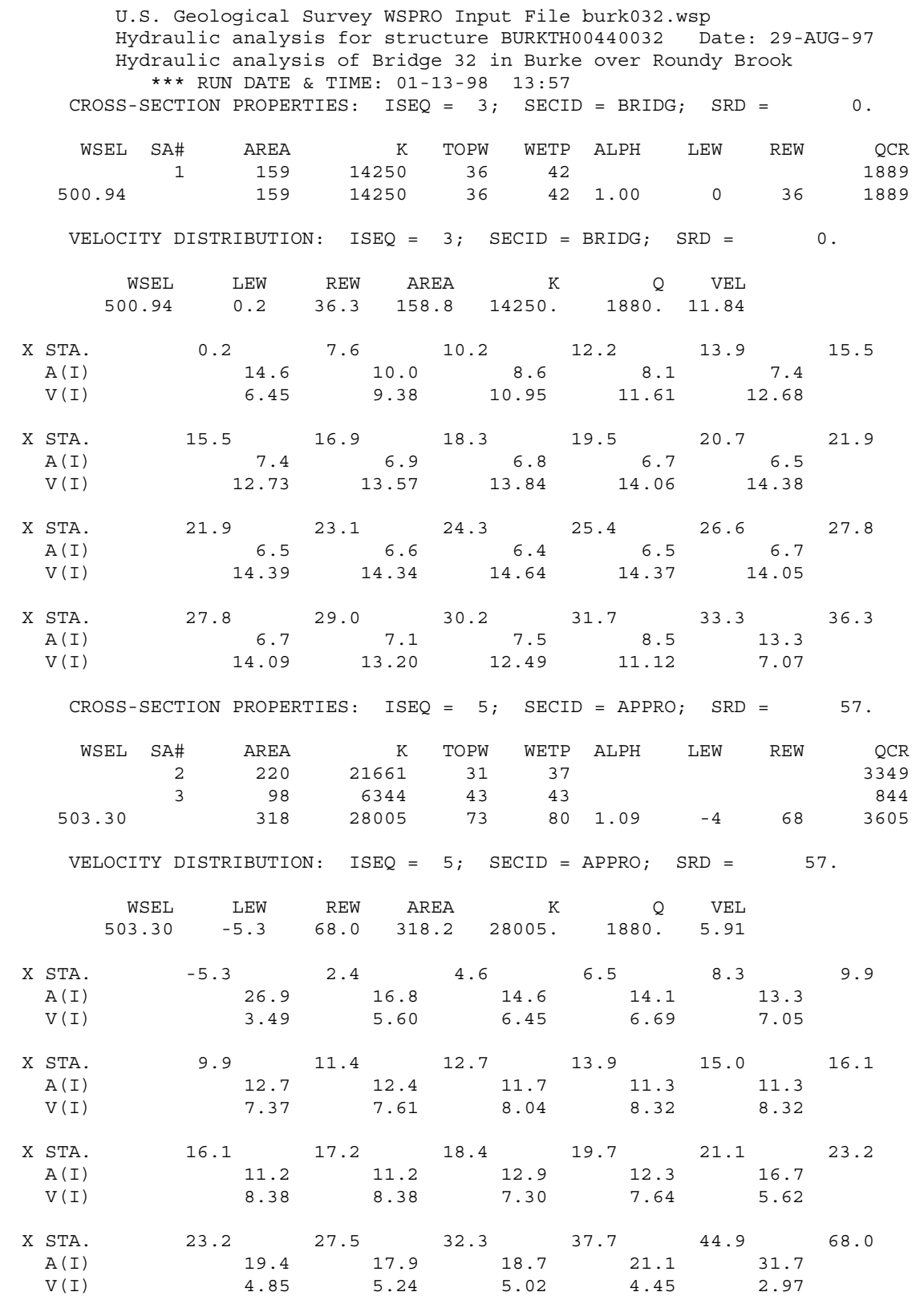


WSPRO OUTPUT FILE (continued)

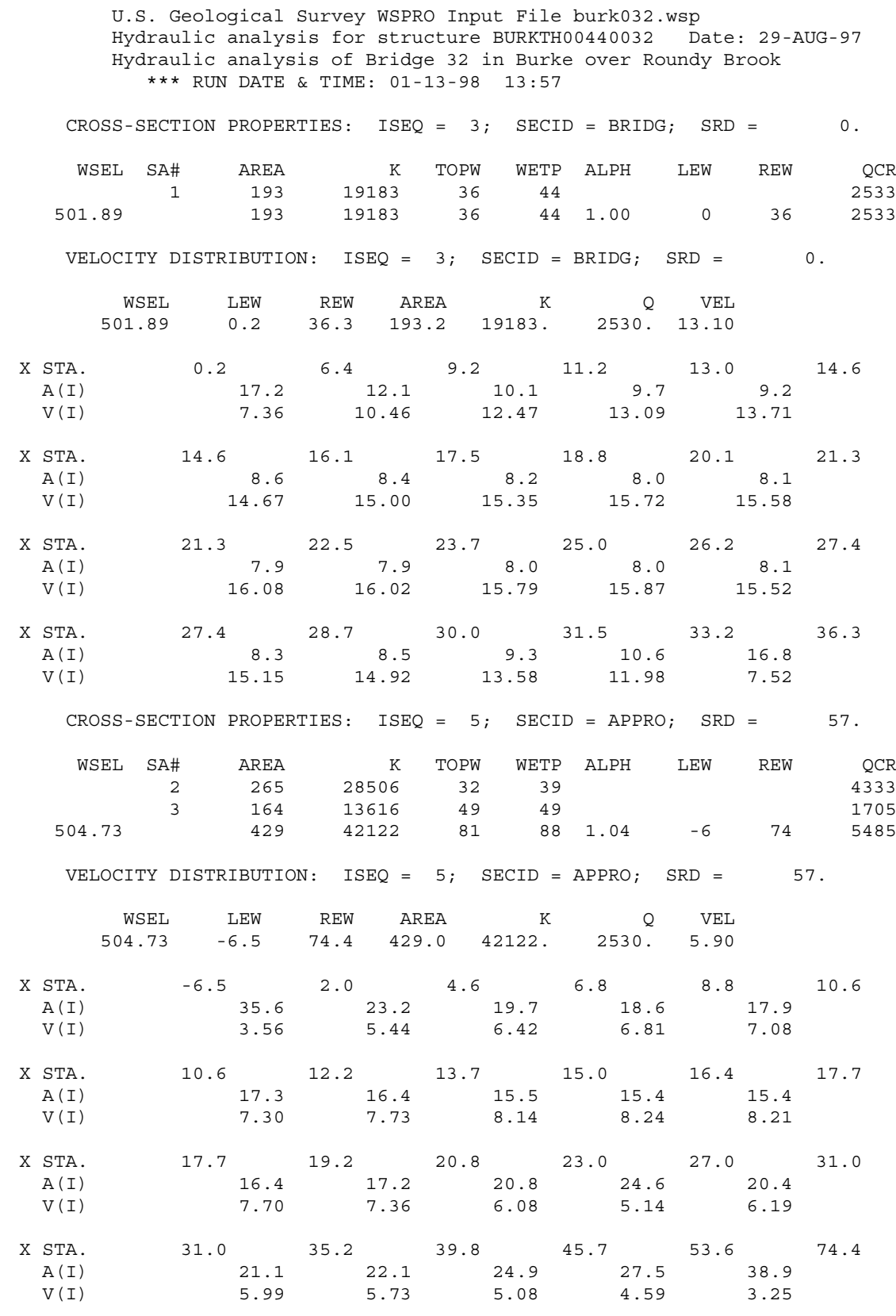


WSPRO OUTPUT FILE (continued)

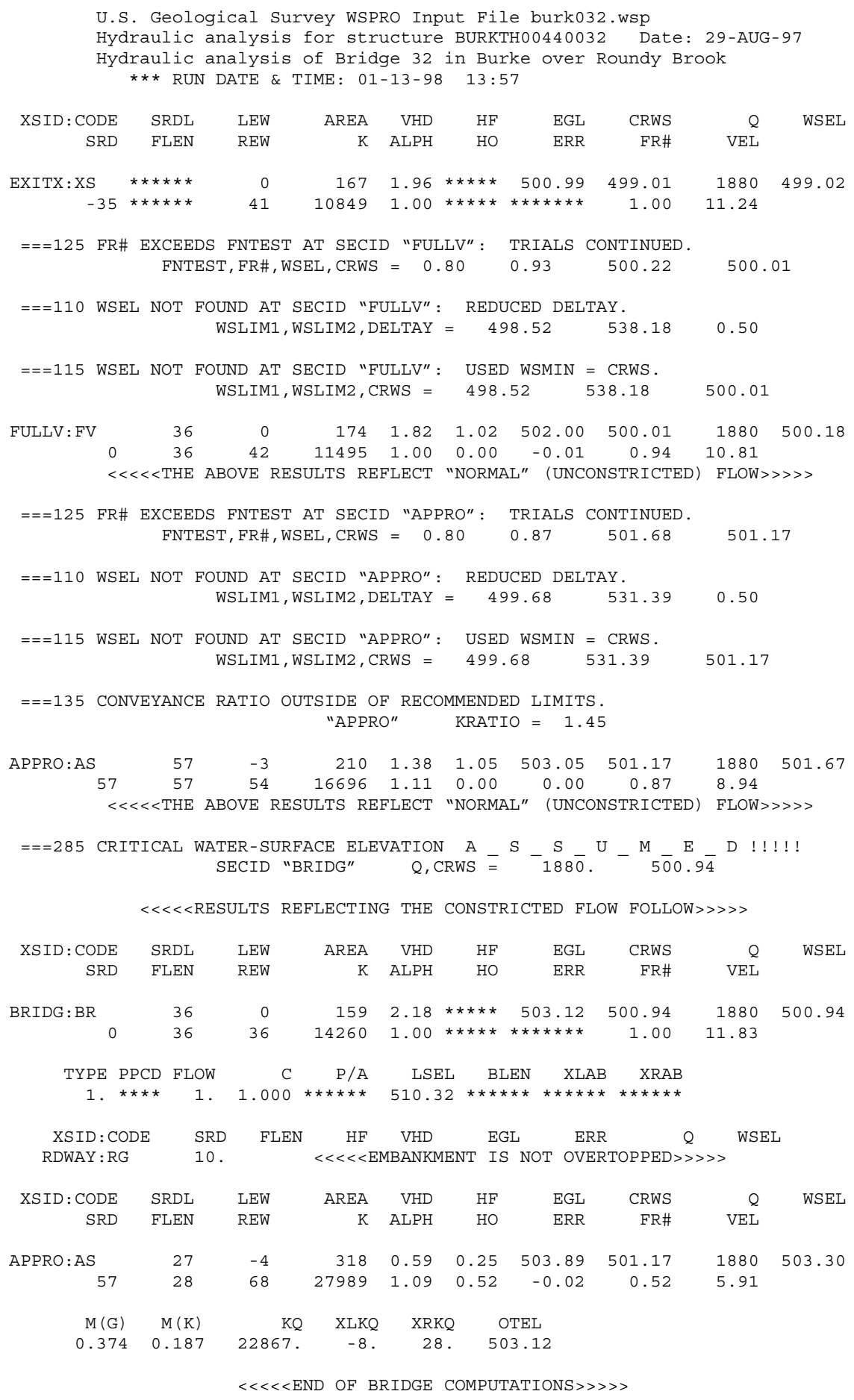


WSPRO OUTPUT FILE (continued)

FIRST USER DEFINED TABLE.

\begin{tabular}{|c|c|c|c|c|c|c|c|c|}
\hline XSID : CODE & SRD & LEW & REW & c & K & AREA & VEL & WSEL \\
\hline EXITX:XS & -36 & -1 & 41. & 1880. & 10849 . & 167. & 11.24 & 499.02 \\
\hline FULLV : FV & 0 . & -1 & 42 . & 1880. & 11495. & 174 . & 10.81 & 500.18 \\
\hline BRIDG : BR & 0 . & 0. & 36. & 1880. & 14260 . & 159. & 11.83 & 500.94 \\
\hline RDWAY : RG & \multicolumn{3}{|c|}{ 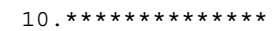 } & \multicolumn{3}{|c|}{ 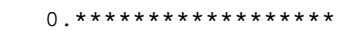 } & \multicolumn{2}{|c|}{$2.00 * \star \star * * * * *$} \\
\hline APPRO: AS & 57. & -5 & 68. & 1880. & 27989 . & 318. & 5.91 & 503.30 \\
\hline XSID : CODE & XLKQ & XRKQ & & & & & & \\
\hline APPRO: AS & -8 . & 28. & 2286 & & & & & \\
\hline
\end{tabular}

SECOND USER DEFINED TABLE.

\begin{tabular}{|c|c|c|c|c|c|c|c|c|c|}
\hline XSID : CODE & CRWS & FR\# & YMIN & YMAX & $\mathrm{HF}$ & HO & VHD & EGL & WSEL \\
\hline EXITX:XS & 499.01 & 1.00 & 493.21 & $537.18 * *$ & 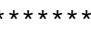 & 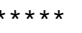 & 1.96 & 500.99 & 499.02 \\
\hline FULLV : FV & 500.01 & 0.94 & 494.21 & 538.18 & 1.02 & 0.00 & 1.82 & 502.00 & 500.18 \\
\hline BRIDG : BR & 500.94 & 1.00 & 495.29 & $510.36 * *$ & $\star \star \star \star \star * \star * \star$ & 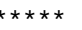 & 2.18 & 503.12 & 500.94 \\
\hline RDWAY : RG & 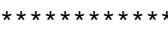 & $\star \star \star \star \star *$ & 511.93 & $524.18 * *$ & 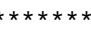 & $\star \star \star * \star * *$ & $* \star \star * \star * *$ & 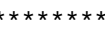 & 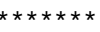 \\
\hline APPRO: AS & 501.17 & 0.52 & 493.22 & 531.39 & 0.25 & 0.52 & 0.59 & 503.89 & 503.30 \\
\hline
\end{tabular}


WSPRO OUTPUT FILE (continued)

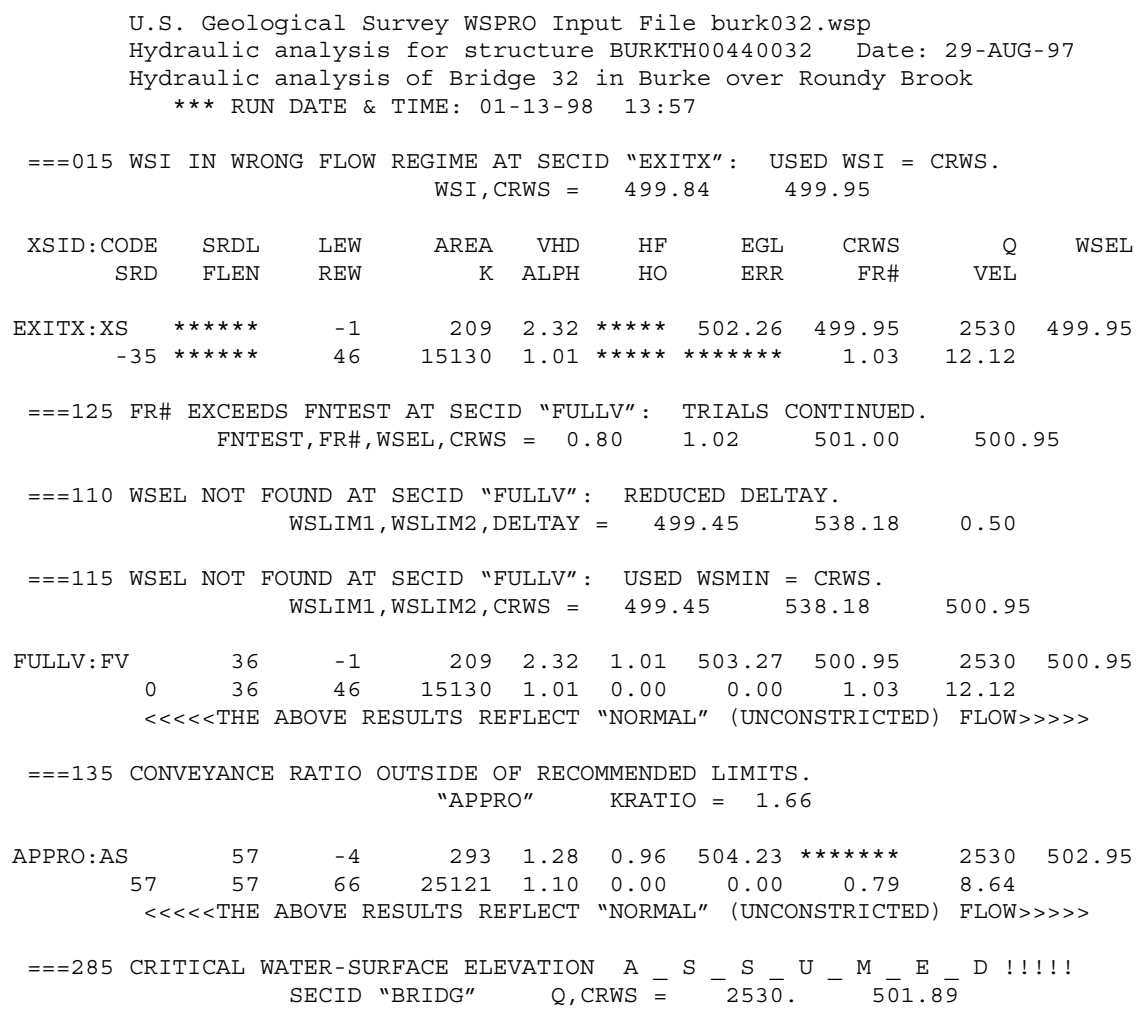

FIRST USER DEFINED TABLE.

\begin{tabular}{|c|c|c|c|c|c|c|c|c|}
\hline XSID : CODE & SRD & LEW & REW & Q & $\mathrm{K}$ & AREA & VEL & WSEL \\
\hline EXITX:XS & -36. & -2 & 46. & 2530 . & 15130. & 209. & 12.12 & 499.95 \\
\hline FULLV : FV & 0 . & -2 & 46. & 2530. & 15130. & 209. & 12.12 & 500.95 \\
\hline BRIDG : BR & 0 . & 0 . & 36 . & 2530. & 19205. & 193. & 13.09 & 501.89 \\
\hline RDWAY : RG & \multicolumn{3}{|c|}{$10 . * * * * * * * * * * * * * *$} & \multicolumn{3}{|c|}{$0 . * * \star * * * * * * * * \star * * * * * * *$} & \multicolumn{2}{|c|}{$2.00 * * * * * * * *$} \\
\hline APPRO: AS & 57. & -7 & 74. & 2530. & 42164 & 429. & 5.89 & 504.73 \\
\hline XSID : CODE & XLKQ & XRKQ & & & & & & \\
\hline APPRO: AS & -6. & 30. & 3188 & & & & & \\
\hline
\end{tabular}

SECOND USER DEFINED TABLE.

$\begin{array}{lrrrrrrrrr}\text { XSID }: \text { CODE } & \text { CRWS } & \text { FR\# } & \text { YMIN } & \text { YMAX } & \text { HF } & \text { HO } & \text { VHD } & \text { EGL } & \text { WSEL } \\ \text { EXITX : XS } & 499.95 & 1.03 & 493.21 & 537.18 * * * * * * * * * * & 2.32 & 502.26 & 499.95 \\ \text { FULLV : FV } & 500.95 & 1.03 & 494.21 & 538.18 & 1.01 & 0.00 & 2.32 & 503.27 & 500.95 \\ \text { BRIDG : BR } & 501.89 & 1.00 & 495.29 & 510.36 * * * * * * * * * * & 2.66 & 504.56 & 501.89 \\ \text { RDWAY : RG } & * * * * * * * * * * * * * * * * & 511.93 & 524.18 * * * * * * * * * * * * * * * * * * * * * * * * * * * * * * * \\ \text { APPRO: AS } & 502.19 & 0.46 & 493.22 & 531.39 & 0.22 & 0.52 & 0.56 & 505.30 & 504.73\end{array}$




\section{APPENDIX C:}

\section{BED-MATERIAL PARTICLE-SIZE DISTRIBUTION}




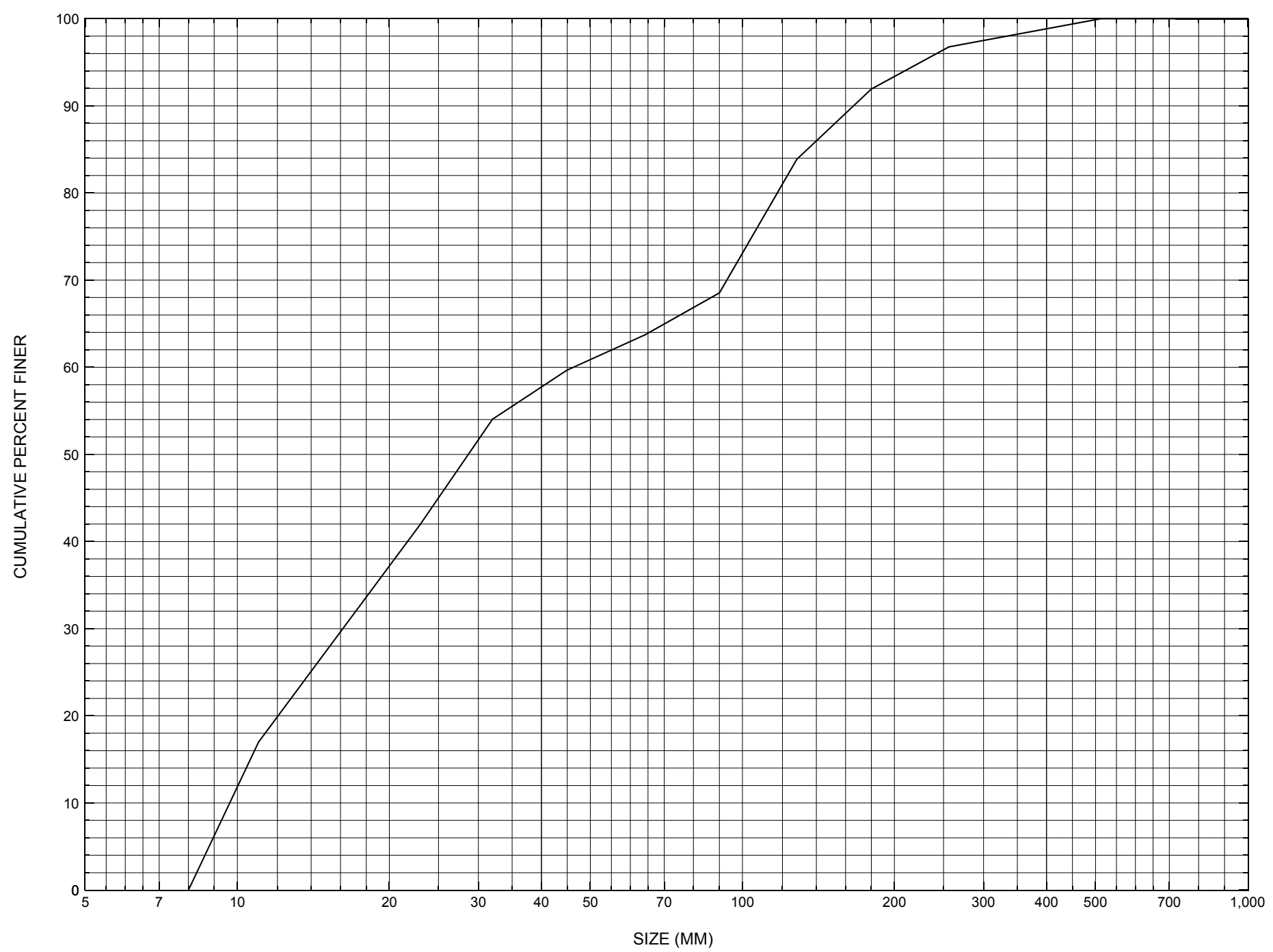

Appendix C. Bed material particle-size distribution for a pebble count in the channel underneath structure BURKTH00440032, in Burke, Vermont. 


\section{APPENDIX D: \\ HISTORICAL DATA FORM}




\section{Structure Number BURKTH00440032}

\section{General Location Descriptive}

Data collected by (First Initial, Full last name) $\mathbf{E}$. BOEHMLER

Date $(M M / D D / Y Y) \_\mathbf{0 3} / \underline{24} / \underline{95}$

Highway District Number (I - 2; nn) $\mathbf{0 7}$

Town (FIPS place code; I - 4; nnnnn) $\mathbf{1 0 4 5 0}$

Waterway (I - 6) ROUNDY BROOK

Route Number TH044

Topographic Map Burke Mountain

Latitude (I - 16; nnnn.n) 44366
County (FIPS county code; I - 3; nnn)

Mile marker (I - 11; nnn.nnn) $\mathbf{0 0 0 0 0 0}$

Road Name (I - 7): -

Vicinity (I - 9) 0.6 MI JCT TH 44 + US 5

Hydrologic Unit Code: $\mathbf{0 1 0 8 0 1 0 2}$

Longitude (i - 17; nnnnn.n) $\mathbf{7 1 5 8 0}$

\section{Select Federal Inventory Codes}

FHWA Structure Number (I - 8) $\mathbf{1 0 0 3 0 2 0 0 3 2 0 3 0 2}$

Maintenance responsibility $(I-21 ; n n) \quad \mathbf{0 3}$

Year built (I - 27; YYYY) 1929

Average daily traffic, ADT (I - 29; nnnnnn) 000200

Year of ADT (I - 30; YY) $\mathbf{9 2}$

Opening skew to Roadway $(I-34 ; n n) \quad \mathbf{0 0}$

Operational status $(I-41 ; X) \quad \mathbf{A}$

Structure type (I - 43; nnn) $\mathbf{3 0 3}$

Approach span structure type (I - 44; nnn) $\mathbf{0 0 0}$

Number of spans (I - 45; nnn) $\mathbf{0 0 1}$

Number of approach spans (I - 46; nnnn) $\mathbf{0 0 0 0}$

Comments:

The structural inspection report of 10/31/94 indicates the structure is a steel girder and floor beam system type bridge with a concrete deck. The abutment walls and wingwalls are concrete. A small section of the concrete footing is reported showing on the right abutment. The right abutment concrete is spalled along its base. Both abutment walls have a few small cracks, leaks, and spalls reported. While the footing is exposed on the right abutment, the report indicates undermining and settling are not evident. Some boulder riprap is noted around the ends of each wingwall and some in small areas where bank erosion has occurred during previous flooding on the banks up- and downstream (Continued, page 32). 


\section{Bridge Hydrologic Data}

Is there hydrologic data available? $\underline{\mathbf{N}}$ if No, type ctrl-n $h \quad$ VTAOT Drainage area $\left(m i^{2}\right)$ : -

Terrain character:

Stream character \& type: -

Streambed material:

Discharge Data (cfs):

$$
\begin{aligned}
& Q_{2.33}- \\
& Q_{50}-
\end{aligned}
$$

Record flood date $(M M / D D / Y Y)$ :

Estimated Discharge (cfs): Ice conditions (Heavy, Moderate, Light) : -

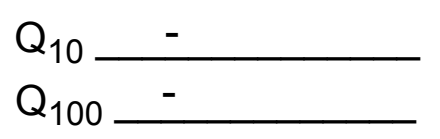

$$
\begin{aligned}
& Q_{25}- \\
& Q_{500}-
\end{aligned}
$$

Water surface elevation $(f t):-$

The stage increases to maximum highwater elevation (Rapidly, Not rapidly):

The stream response is (Flashy, Not flashy):

Describe any significant site conditions upstream or downstream that may influence the stream's stage: -

Watershed storage area (in percent): _ _ \%

The watershed storage area is: - (1-mainly at the headwaters; 2- uniformly distributed; 3-immediatly upstream oi the site)

Water Surface Elevation Estimates for Existing Structure:

\begin{tabular}{|l|l|l|l|l|l|}
\hline Peak discharge frequency & $Q_{2.33}$ & $Q_{10}$ & $Q_{25}$ & $Q_{50}$ & $Q_{100}$ \\
Water surface elevation (ft)) & - & - & - & - & - \\
Velocity (ft/sec) & - & - & - & - & - \\
\hline
\end{tabular}

Long term stream bed changes: -

Is the roadway overtopped below the $\mathrm{Q}_{100}$ ? (Yes, No, Unknown): $\mathbf{U}$ Frequency: Relief Elevation (ft): Discharge over roadway at $Q_{100}\left(f^{3} / \mathrm{sec}\right)$ :

Are there other structures nearby? (Yes, No, Unknown): $\underline{\mathbf{U}}$ Upstream distance (miles): Town: If No or Unknown, type ctrl-n os Highway No. : Structure No. : Year Built:

Clear span (ft): Clear Height $(f t)$ : Full Waterway $\left(f^{2}\right)$ : 
Downstream distance (miles): Town: Year Built:

Highway No. : Structure No. : Structure Type:

Clear span $(f t):$ Clear Height $(f t)$ : Full Waterway $\left(f^{2}\right)$ :

Comments:

An old log is reported across the channel just upstream of the bridge. Channel scour and point bar development are reported as minor at this site. The foundation type recorded for this bridge is unknown .

\section{USGS Watershed Data}

Watershed Hydrographic Data

Drainage area (DA) $\mathbf{9 . 2 4}$

Watershed storage (ST)

Bridge site elevation

Main channel length 890 10.59 $10 \%$ channel length elevation $\mathbf{9 1 0}$

Main channel slope

(S) 93.15 $\mathrm{ft} / \mathrm{mi}$

Watershed Precipitation Data

Average site precipitation in Average headwater precipitation in

Maximum 2yr-24hr precipitation event $(124,2)$ in

Average seasonal snowfall (Sn) $\mathrm{ft}$ 


\section{Bridge Plan Data}

Are plans available? $\mathbf{N} \quad$ If no, type ctrl-n pl Date issued for construction (MM / YYYY):

Project Number

Minimum channel bed elevation:

Low superstructure elevation: USLAB DSLAB USRAB DSRAB Benchmark location description:

There is no benchmark information available.

Reference Point (MSL, Arbitrary, Other):

Datum (NAD27, NAD83, Other):

Foundation Type: 4

If 1: Footing Thickness

If 2: Pile Type:

If 3: Footing bottom elevation:

Is boring information available? $\mathbf{N}$

Foundation Material Type: $\mathbf{3}$

(1-Spreadfooting; 2-Pile; 3- Gravity; 4-Unknown)

Footing bottom elevation: -

Briefly describe material at foundation bottom elevation or around piles:

There is no foundation material information available.

Comments:

There are no bridge plans available. 


\section{Cross-sectional Data}

Is cross-sectional data available? $\underline{\mathbf{Y}}$

If no, type ctrl-n xs

Source (FEMA, VTAOT, Other)? VTAOT

This cross section is the downstream face. The low chord elevations are from the survey log Comments: done for this report on $8 / 8 / 95$. The low chord to bed length data are from the sketch attached to a bridge inspection report dated 10/31/94. The sketch was done on 9/10/92.

\begin{tabular}{|l|l|l|l|l|l|l|l|l|l|l|l|}
\hline Station & $\mathbf{0}$ & $\mathbf{4 . 7}$ & $\mathbf{1 3 . 4}$ & $\mathbf{1 9 . 7}$ & $\mathbf{2 3}$ & $\mathbf{2 8}$ & $\mathbf{3 3 . 7}$ & - & - & - & - \\
\hline Feature & RAB & - & - & - & - & - & LAB & - & - & - & - \\
\hline $\begin{array}{l}\text { Low chord } \\
\text { elevation }\end{array}$ & $\mathbf{5 1 0 . 4}$ & $\mathbf{5 1 0 . 4}$ & $\mathbf{5 1 0 . 4}$ & $\mathbf{5 1 0 . 3}$ & $\mathbf{5 1 0 . 3}$ & $\mathbf{5 1 0 . 3}$ & $\mathbf{5 1 0 . 3}$ & - & - & - & - \\
\hline $\begin{array}{l}\text { Bed } \\
\text { elevation }\end{array}$ & $\mathbf{4 9 6 . 6}$ & $\mathbf{4 9 6 . 1}$ & $\mathbf{4 9 5 . 6}$ & $\mathbf{4 9 6 . 5}$ & $\mathbf{4 9 7 . 1}$ & $\mathbf{4 9 9 . 0}$ & $\mathbf{4 9 8 . 8}$ & - & - & - & - \\
\hline $\begin{array}{l}\text { Low chord } \\
\text { to bed }\end{array}$ & $\mathbf{1 3 . 8}$ & $\mathbf{1 4 . 3}$ & $\mathbf{1 4 . 8}$ & $\mathbf{1 3 . 8}$ & $\mathbf{1 3 . 2}$ & $\mathbf{1 1 . 3}$ & $\mathbf{1 1 . 5}$ & - & - & - & - \\
\hline Station & - & - & - & - & - & - & - & - & - & - & - \\
\hline Feature & - & - & - & - & - & - & - & - & - & - & - \\
\hline $\begin{array}{l}\text { Low chord } \\
\text { elevation }\end{array}$ & - & - & - & - & - & - & - & - & - & - & - \\
\hline $\begin{array}{l}\text { Bed } \\
\text { elevation }\end{array}$ & - & - & - & - & - & - & - & - & - & - & - \\
\hline $\begin{array}{l}\text { Low chord } \\
\text { to bed }\end{array}$ & - & - & - & - & - & - & - & - & - & - & - \\
\hline
\end{tabular}

Source (FEMA, VTAOT, Other)?

Comments: -

\begin{tabular}{|l|l|l|l|l|l|l|l|l|l|l|l|}
\hline Station & - & - & - & - & - & - & - & - & - & - & - \\
\hline Feature & - & - & - & - & - & - & - & - & - & - & - \\
\hline $\begin{array}{l}\text { Low chord } \\
\text { elevation }\end{array}$ & - & - & - & - & - & - & - & - & - & - & - \\
\hline $\begin{array}{l}\text { Bed } \\
\text { elevation }\end{array}$ & - & - & - & - & - & - & - & - & - & - & - \\
\hline $\begin{array}{l}\text { Low chord } \\
\text { to bed }\end{array}$ & - & - & - & - & - & - & - & - & - & - & - \\
\hline Station & - & - & - & - & - & - & - & - & - & - & - \\
\hline Feature & - & - & - & - & - & - & - & - & - & - & - \\
\hline $\begin{array}{l}\text { Low chord } \\
\text { elevation }\end{array}$ & - & - & - & - & - & - & - & - & - & - & - \\
\hline $\begin{array}{l}\text { Bed } \\
\text { elevation }\end{array}$ & - & - & - & - & - & - & - & - & - & - & - \\
\hline $\begin{array}{l}\text { Low chord } \\
\text { to bed }\end{array}$ & - & - & - & - & - & - & - & - & - & - & - \\
\hline
\end{tabular}




\section{APPENDIX E: \\ LEVEL I DATA FORM}


U. S. Geological Survey

Bridge Field Data Collection and Processing Form

Qa/Qc Check by: $\mathbf{R B}$ Date: $\mathbf{3 / 1 / 9 6}$

\section{Structure Number}

BURKTH00440032

Computerized by: $\underline{\mathbf{R B}}$ Date: $3 / 1 / 96$

Reviewd by: MS Date: $\underline{\mathbf{5} / \mathbf{4} / 98}$

\section{A. General Location Descriptive}

1. Data collected by (First Initial, Full last name) E. BOEHMLER

Date $(M M / D D / Y Y) \underline{\mathbf{0 8}} / \underline{\mathbf{0 8}} / \underline{1995}$

2. Highway District Number $\mathbf{0 7}$

County_Caledonia (005)

Waterway (I - 6) ROUNDY BROOK

Route Number $\mathbf{T H 0 4 4}$

3. Descriptive comments:

The bridge is located about 0.6 miles from the intersection of TH044 with US Route 5.
Mile marker $\mathbf{0 0 0 0}$

Town BURKE (10450)

Road Name -

Hydrologic Unit Code: $\mathbf{0 1 0 8 0 1 0 2}$

\section{B. Bridge Deck Observations}
4. Surface cover... LBUS 6
RBUS 4
LBDS 6
RBDS 6
Overall 6

(2b us,ds,lb,rb: 1- Urban; 2- Suburban; 3- Row crops; 4- Pasture; 5- Shrub- and brushland; 6- Forest; 7- Wetland)
5. Ambient water surface... US 2
UB 2
DS 2
(1- pool; 2- riffle)

6. Bridge structure type 1 (1- single span; 2- multiple span; 3- single arch; 4- multiple arch; 5-cylindrical culvert; 6- box culvert; or 7- other)
7. Bridge length $\mathbf{4 3}$
(feet)
Span length $\underline{39}$
(feet)
Bridge width 17.5 (feet)

\section{Road approach to bridge:}
8. LB 2
RB 2
( 0 even, 1- lower, 2- higher)
9. LB_
RB $\underline{2}$
(1-Paved, 2- Not paved)

10. Embankment slope (run / rise in feet / foot)

US left

US right

\begin{tabular}{|c|c|c|c|}
\hline \multicolumn{2}{|c|}{ Protection } & \multirow{2}{*}{ 13.Erosion } & 14.Severity \\
\hline 11.Type & 12.Cond. & $\mathbf{2}$ & $\underline{\mathbf{2}}$ \\
\hline $\mathbf{0}$ & - & $\underline{\mathbf{2}}$ & $\mathbf{0}$ \\
\hline $\mathbf{0}$ & - & $\mathbf{0}$ & $\mathbf{2}$ \\
\hline $\mathbf{0}$ & - & $\mathbf{2}$ & $\mathbf{2}$ \\
$\mathbf{0}$ & - & $\underline{\mathbf{2}}$ \\
\hline
\end{tabular}

Bank protection types: 0- none; 1- < 12 inches;

2- < 36 inches; 3- < 48 inches;

4- < 60 inches; 5- wall / artificial levee

Bank protection conditions: 1- good; 2- slumped;

3- eroded; 4- failed

Erosion: 0 - none; 1- channel erosion; 2 -

road wash; 3- both; 4- other

Erosion Severity: 0 - none; 1- slight; 2- moderate; 3- severe

\section{Channel approach to bridge (BF):}

15. Angle of approach: $\mathbf{0}$

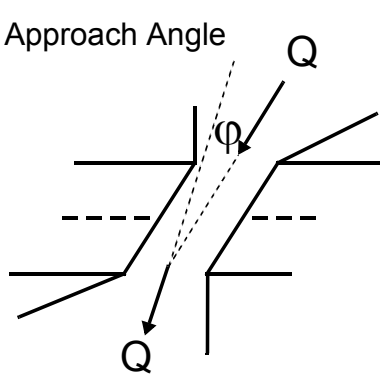

17. Channel impact zone 1:

Where? LB $(L B, R B)$

Range? 75 feet US

Channel impact zone 2:

Where? RB (LB, RB)

Range? $\underline{\mathbf{0}}$ feet $\underline{\mathbf{U S}}$

Impact Severity: 0- none to very slight; 1- Slight; 2- Moderate; 3- Severe
16. Bridge skew: $\mathbf{0}$ Bridge Skew Angle

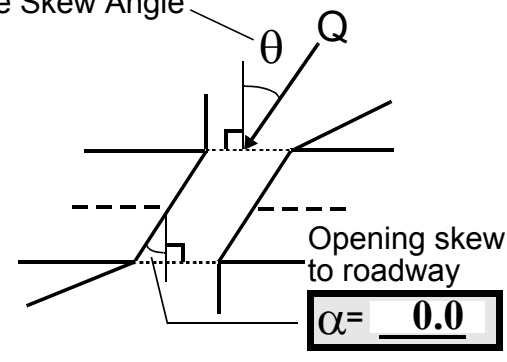

\section{Exist? $\mathbf{Y}(Y$ or $N)$}

Severity $\underline{3}$

(US, UB, DS) to $\underline{\mathbf{5 0}}$ feet $\underline{\mathbf{U S}}$

Exist? Y $(Y$ or $N)$

Severity 1

$U B, D S)$ to $\underline{\mathbf{0} \quad \text { feet }} \underline{\mathbf{D S}}$ 
18. Bridge Type: 1a

1a- Vertical abutments with wingwalls

$1 \mathrm{~b}$ - Vertical abutments without wingwalls

2- Vertical abutments and wingwalls, sloping embankment Wingwalls parallel to abut. face

3- Spill through abutments

4- Sloping embankment, vertical wingwalls and abutments

Wingwall angle less than $90^{\circ}$.

19. Bridge Deck Comments (surface cover variations, measured bridge and span lengths, bridge type variations, approach overflow width, etc.)

7. The bridge dimensions are from the VTAOT files. The measured bridge length was 41.6 feet, the span length was 38.6 feet, and the bridge width was 17.5 feet.

\section{Upstream Channel Assessment}

\begin{tabular}{|c|c|c|c|c|c|c|c|c|c|c|}
\hline \multicolumn{5}{|c|}{ 21. Bank height (BF) 22. Bank angle (BF) } & \multicolumn{2}{|c|}{ 26. \% Veg. cover (BF) } & \multicolumn{2}{|c|}{ 27. Bank material (BF } & \multicolumn{2}{|c|}{ 28. Bank erosion (BF } \\
\hline 20. SRD & LB & RB & LB & RB & LB & RB & LB & RB & LB & RB \\
\hline 38.5 & 9.0 & & & 2.0 & 3 & 1 & 213 & 213 & 2 & 1 \\
\hline 3. Ban & & & 24. & width & 45.0 & 25. Th & eg dep & 33.0 & 9. Bed & 231 \\
\hline
\end{tabular}

30 .Bank protection type: LB $\underline{\mathbf{0}}$

RB 0

31. Bank protection condition: LB $\mathrm{RB}$ -

SRD - Section ref. dist. to US face \% Vegetation (Veg) cover: 1- 0 to 25\%; 2- 26 to 50\%; 3- 51 to $75 \%$; 4- 76 to $100 \%$

Bed and bank Material: 0- organics; 1- silt / clay, <1/16mm; 2- sand, 1/16 - 2mm; 3- gravel, 2 - 64mm;

4- cobble, 64 - 256mm; 5- boulder, > 256mm; 6- bedrock; 7- manmade

Bank Erosion: 0- not evident; 1- light fluvial; 2- moderate fluvial; 3- heavy fluvial / mass wasting

Bank protection types: 0- absent; 1- < 12 inches; 2- < 36 inches; 3- < 48 inches; 4- < 60 inches; 5- wall / artificial levee

Bank protection conditions: 1-good; 2- slumped; 3- eroded; 4- failed

32. Comments (bank material variation, minor inflows, protection extent, etc.):

There is some stone fill on the streambed from 20 feet US to the US face. The water is generally pooled beyond 20 feet US from the US face of the bridge. There are 2 or 3 whole tree trunks lodged on both banks forming a blockage across the channel about 60 feet US. The lodged trees have captured other debris, mainly leaves and branches, resulting in greater blockage along the left-bank side compared to the right-bank side. 
33.Point/Side bar present? $\mathbf{N}(Y$ or $N$. if $N$ type ctrl-n pb)34. Mid-bar distance: -

35. Mid-bar width: -

36. Point bar extent: feet (US, UB) to feet (US, UB, DS) positioned $\%$ LB to $\% \mathrm{RB}$

37. Material: -

38. Point or side bar comments (Circle Point or Side; Note additional bars, material variation, status, etc.):

NO POINT BARS

39. Is a cut-bank present? $\mathbf{Y}$ (Y or if $N$ type ctrl-n cb)

40. Where? $\underline{\mathbf{L B}}$ (LB or RB)

41. Mid-bank distance: 65

42. Cut bank extent: $\underline{\mathbf{1 0 0}}$ feet $\underline{\mathbf{U S}}$ (US, UB) to $\underline{\mathbf{5 0}}$ feet $\underline{\mathbf{U S}}$ (US, UB, DS)

43. Bank damage: 1

(1- eroded and/or creep; 2- slip failure; 3- block failure)

44. Cut bank comments (eg. additional cut banks, protection condition, etc.):

The bank now is partially protected by a narrow sand-bar ridge that has developed. There is a debris pile that blocks some of the flow along the left bank just DS of the cut-bank.

\section{Is channel scour present? $\mathbf{N}$ ( $Y$ or if $N$ type ctrl-n cs)}

47. Scour dimensions: Length Width -

Depth : -

46. Mid-scour distance: -

48. Scour comments (eg. additional scour areas, local scouring process, etc.):

The bed material US of the bridge is much sandier and the ambient thalweg is deeper than under the bridge and DS. The bridge channel forms a control and water is generally pooled from 20 feet US of the US face to greater than 200 feet US.

\section{Are there major confluences? $\mathbf{N}$}

51. Confluence 1: Distance Confluence 2: Distance 52. Enters on Enters on 54. Confluence comments (eg. confluence name):

\section{NO MAJOR CONFLUENCES}

50. How many? -

53. Type(1-perennial; 2- ephemeral)

Type (1-perennial; 2-ephemeral)

\section{Under Bridge Channel Assessment}

55. Channel restraint (BF)? LB 2

\begin{tabular}{|ccccc|}
\hline \multicolumn{2}{|c}{ 56. Height (BF) } & \multicolumn{3}{c}{57 Angle (BF) } \\
LB & RB & LB & RB \\
$\mathbf{2 2 . 0}$ & & & $\mathbf{4 . 0}$ & \\
\hline
\end{tabular}

58. Bank width (BF) (1- natural bank; 2- abutment; 3- artificial levee)

Bed and bank Material: 0- organics; 1- silt / clay, < 1/16mm; 2- sand, 1/16 - 2mm; 3- gravel, 2 - 64mm; 4- cobble, 64 - 256mm; 5- boulder, > 256mm; 6- bedrock; 7- manmade

62. Erosion (BF)

LB RB

LB RB

$2 \quad 7$

7

60. Thalweg depth $\lcm{90.0}$
63. Bed Material -

Bank Erosion: 0- not evident; 1- light fluvial; 2- moderate fluvial; 3- heavy fluvial / mass wasting

64. Comments (bank material variation, minor inflows, protection extent, etc.):

345

At least part of the boulder bed material is stone fill. Among the boulder-sized stone fill are some blocks of old concrete. 
65. Debris and Ice Is there debris accumulation?

$(Y$ or $N)$ 66. Where? $\underline{Y}$

(1- Upstream; 2- At bridge; 3- Both)

67. Debris Potential US (1-Low; 2- Moderate; 3- High)

68. Capture Efficiency 3

(1-Low; 2- Moderate; 3- High)

69. Is there evidence of ice build-up? 2 (Y or $N)$

Ice Blockage Potential $\underline{\mathbf{N}}$

(1- Low; 2- Moderate; 3- High)

70. Debris and Ice Comments:

2

The upstream banks are well vegetated. The 90 degree bend in the upstream channel and the abundant vegetation attribute to the high debris potential.

\begin{tabular}{|l|c|c|c|c|c|c|c|c|}
\hline Abutments & $\begin{array}{c}71 . \text { Attack } \\
\angle \text { (BF) }\end{array}$ & $\begin{array}{c}72 \text {. Slope } \angle \\
\text { (Qmax) }\end{array}$ & $\begin{array}{c}\text { 73. Toe } \\
\text { loc. (BF) }\end{array}$ & $\begin{array}{c}\text { 74. Scour } \\
\text { Condition }\end{array}$ & $\begin{array}{c}75 . \text { Scour } \\
\text { depth }\end{array}$ & $\begin{array}{c}\text { 76. Exposure } \\
\text { depth }\end{array}$ & 77. Material & 78. Length \\
\hline LABUT & & - & $\mathbf{9 0}$ & $\mathbf{0}$ & $\mathbf{0}$ & $\mathbf{0}$ & $\mathbf{0}$ & $\mathbf{9 0 . 0}$ \\
\hline RABUT & $\mathbf{1}$ & $\mathbf{5}$ & $\mathbf{9 0}$ & & & $\mathbf{2}$ & $\mathbf{2}$ & $\mathbf{3 6 . 5}$ \\
\hline
\end{tabular}

Pushed: $L B$ or RB

Toe Location (Loc.): 0- even, 1- set back, 2- protrudes

Scour cond.: 0- not evident; 1- evident (comment); 2- footing exposed; 3-undermined footing; 4- piling exposed; 5- settled; 6- failed

Materials: 1- Concrete; 2- Stone masonry or drywall; 3- steel or metal; 4- wood

79. Abutment comments (eg. undermined penetration, unusual scour processes, debris, etc.):

0

0.5

1

Exposure of the right abutment footing varies from 0.2 to 0.5 feet. There is a sand point bar along the left abutment. The right abutment is unprotected.

80. Wingwalls:

Exist? Material? Scour Scour Exposure 81. Condition? depth? depth?

USLWW:

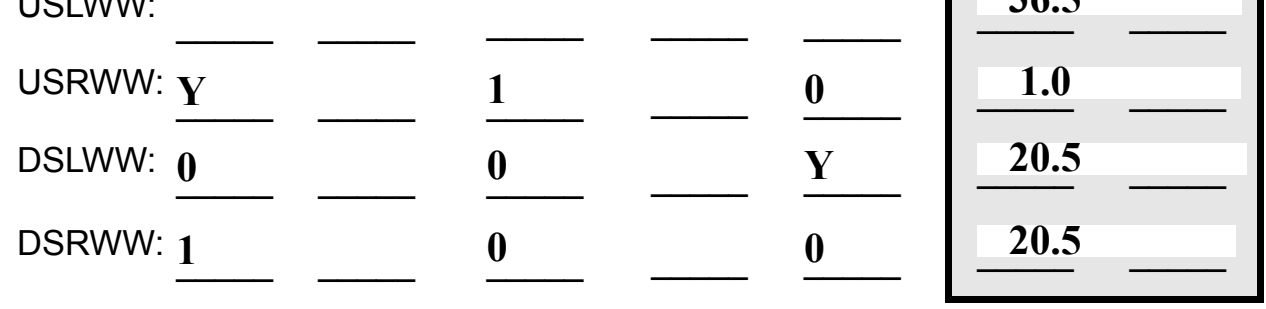

Wingwall materials: 1- Concrete; 2- Stone masonry or drywall; 3- steel or metal; 4- wood

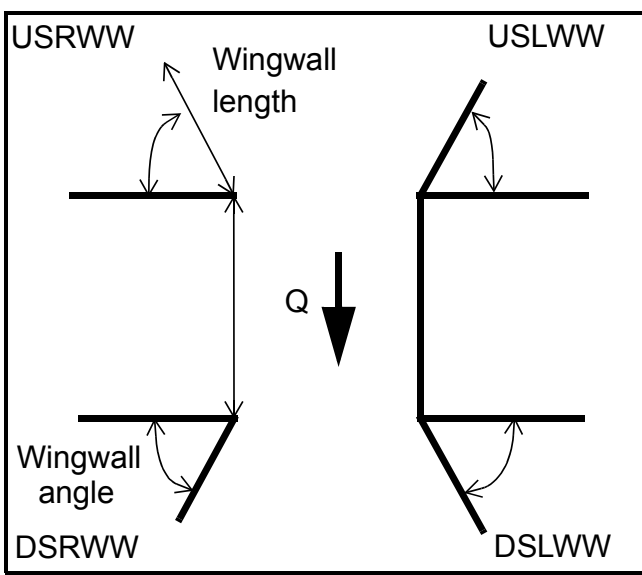

82. Bank / Bridge Protection:

\begin{tabular}{|l|l|l|l|l|l|l|c|c|}
\hline Location & USLWW & USRWW & LABUT & RABUT & LB & RB & DSLWW & DSRWW \\
\hline Type & $\mathbf{0}$ & $\mathbf{0}$ & $\mathbf{Y}$ & $\mathbf{0}$ & - & $\mathbf{1}$ & - & - \\
\hline Condition & $\mathbf{Y}$ & $\mathbf{0}$ & $\mathbf{1}$ & $\mathbf{0 . 5}$ & - & $\mathbf{1}$ & - & - \\
\hline Extent & $\mathbf{1}$ & $\mathbf{0}$ & $\mathbf{2}$ & $\mathbf{0}$ & $\mathbf{2}$ & $\mathbf{0}$ & $\mathbf{0}$ & - \\
\hline
\end{tabular}

Bank / Bridge protection types: 0- absent; 1- < 12 inches; 2- < 36 inches; 3- < 48 inches; 4- < 60 inches; 
83. Wingwall and protection comments (eg. undermined penetration, unusual scour processes, etc.):

-
-
-
-
-
2
1
1
2
1
3

Piers:

84. Are there piers? Sto (Y or if $N$ type ctrl-n pr)

\begin{tabular}{|l|l|l|l|l|l|l|l|}
\hline \multirow{2}{*}{$\begin{array}{l}85 . \\
\text { Pier no. }\end{array}$} & \multicolumn{3}{|c|}{ width (w) feet } & \multicolumn{3}{c|}{ elevation (e) feet } \\
\cline { 2 - 8 } & w1 & w2 & w3 & e@w1 & e@w2 & e@w3 \\
\hline Pier 1 & & & & $\mathbf{6 0 . 0}$ & $\mathbf{1 2 . 0}$ & $\mathbf{4 5 . 0}$ \\
\hline Pier 2 & & & & $\mathbf{1 2 . 0}$ & $\mathbf{3 5 . 0}$ & $\mathbf{1 1 . 5}$ \\
\hline Pier 3 & & & - & $\mathbf{4 5 . 0}$ & $\mathbf{1 2 . 0}$ & - \\
\hline Pier 4 & - & - & - & - & - & - \\
Nyyyy
\end{tabular}

\begin{tabular}{|l|l|l|l|l|}
\hline Level 1 Pier Descr. & \multicolumn{1}{|c|}{1} & \multicolumn{1}{|c|}{2} & \multicolumn{1}{|c|}{3} & \multicolumn{1}{|c|}{4} \\
\hline 86. Location (BF) & ne fill & wall. & wing- & may be \\
\hline 87. Type & pro- & The & wall & cov- \\
\hline 88. Material & tects & only & is & ering \\
\hline 89. Shape & the & visi- & chan & stone \\
\hline 90. Inclined? & US & ble & nel & fill. \\
\hline 91. Attack $\angle$ (BF) & right & pro- & fill & The \\
\hline 92. Pushed & wing & tec- & point & DS \\
\hline 93. Length (feet) & - & - & - & - \\
\hline 94. \# of piles & wall & tion & -bar & left \\
\hline 95. Cross-members & and & on & mate & wing \\
\hline 96. Scour Condition & DS & the & rial & wall \\
\hline 97. Scour depth & right & US & whic & is \\
\hline 98. Exposure depth & wing & left & h & pro- \\
\hline
\end{tabular}

LFP, LTB, LB, MCL, MCM, MCR, RB, RTB, RFP

1- Solid pier, 2-column, 3- bent

1-Wood; 2- concrete; 3- metal; 4- stone

1- Round; 2- Square; 3- Pointed

Y-yes; $N-$ no

$L B$ or $R B$

0- none; 1- laterals; 2- diagonals; 3- both

0- not evident; 1- evident (comment);

2- footing exposed; 3- piling exposed;

4- undermined footing; 5- settled; 6- failed 
99. Pier comments (eg. undermined penetration, protection and protection extent, unusual scour processes, etc.): tected with stone fill.

$\mathbf{N}$

100.

\section{E. Downstream Channel Assessment}

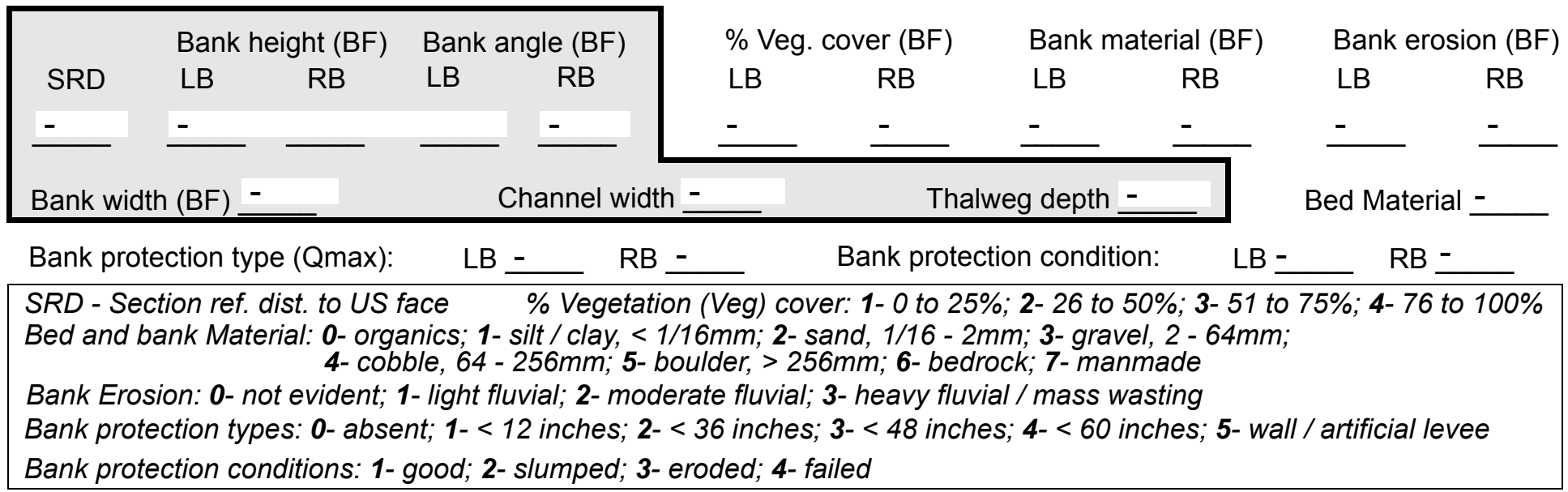

Comments (eg. bank material variation, minor inflows, protection extent, etc.):

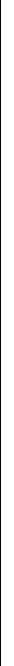

\section{Is a drop structure present? __ ( $Y$ or $N$, if $N$ type ctrl-n $d s) \quad$ 102. Distance: ___ feet}

103. Drop: __ feet 104. Structure material: ___ (1- steel sheet pile; 2- wood pile; 3- concrete; 4- other)

105. Drop structure comments (eg. downstream scour depth): 
106. Point/Side bar present? (Y or $N$. if $N$ type ctrl-n pb)Mid-bar distance:

Mid-bar width: -

Point bar extent: feet (US, UB, DS) to feet (US, UB, DS) positioned $\%$ LB to $\% \mathrm{RB}$ Material:

Point or side bar comments (Circle Point or Side; note additional bars, material variation, status, etc.):

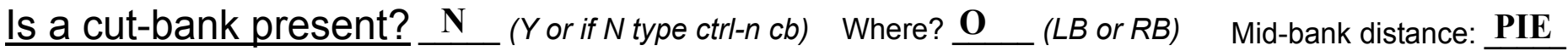
Cut bank extent: RS feet__ (US, UB, DS) to feet (US, UB, DS)

Bank damage: (1- eroded and/or creep; 2- slip failure; 3- block failure)

Cut bank comments (eg. additional cut banks, protection condition, etc.):

Is channel scour present? (Y or if $N$ type ctrl-n cs) Width 235 Depth: $\mathbf{5 4 3}$ Scour dimensions: Length 4

Scour comments (eg. additional scour areas, local scouring process, etc.): 435

2

0

1

Are there major confluences? - (Y or if $N$ type ctrl-n mc) Confluence 1: Distance right Enters on ban ( $L B$ or $R B)$ Enters on $\underline{\mathbf{S}}$ ( $L B$ or $R B)$

Mid-scour distance: 4

Positioned 2 $\%$ LB to 1 $\%$ RB

Confluence comments (eg. confluence name):

How many? The

Type $\underline{\mathbf{k}}$ (1- perennial; 2- ephemeral)

Type fewe (1- perennial; 2- ephemeral)

$r$ signs of erosion than the left bank. The trees along the left bank beyond 75 feet DS are leaning at approximately a 30 degree angle from vertical toward the channel. There is a tree from the left bank lying across the

\section{F. Geomorphic Channel Assessment}

$\begin{array}{ll}\text { 107. Stage of reach evolution cha } & \text { 1- Constructed } \\ & \text { 2-Stable } \\ \text { 3- Aggraded } \\ \text { 4- Degraded } \\ \text { 5- Laterally unstable } \\ \text { 6- Vertically and laterally unstable }\end{array}$


108. Evolution comments (Channel evolution not considering bridge effects; See HEC-20, Figure 1 for geomorphic descriptors):

nnel DS, with its top resting at the top of the right bank near 100 feet DS. Stone fill is found as far as 50 feet DS in the channel. The left bank protection extends from the DS left wingwall to about 25 feet DS. 


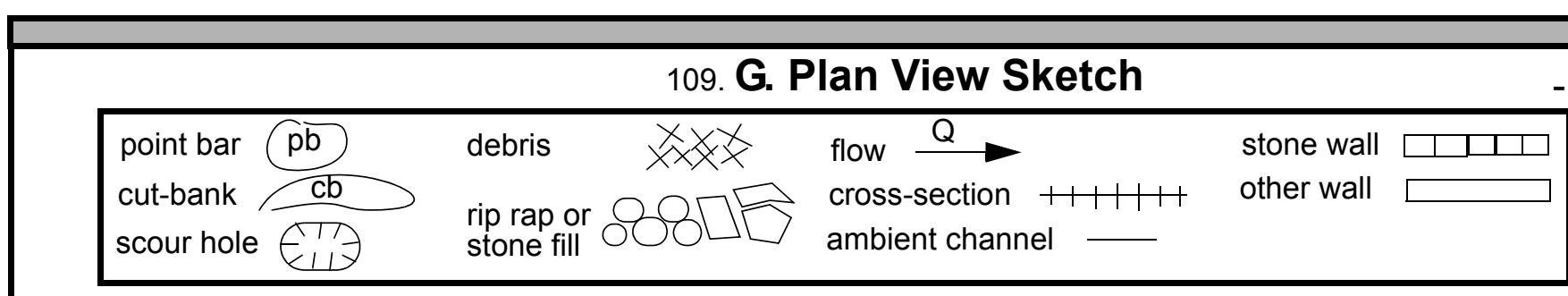


APPENDIX F:

SCOUR COMPUTATIONS 


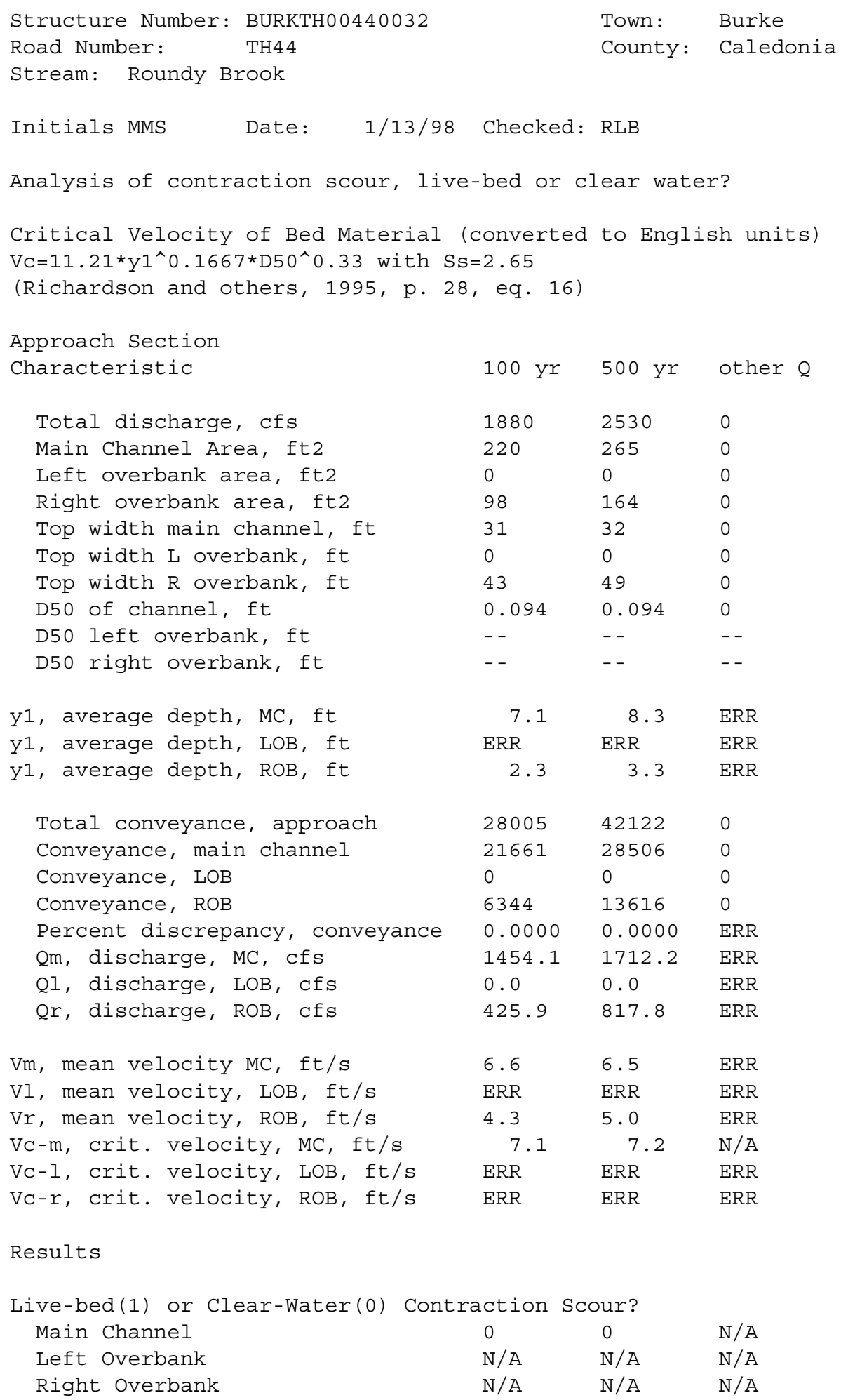




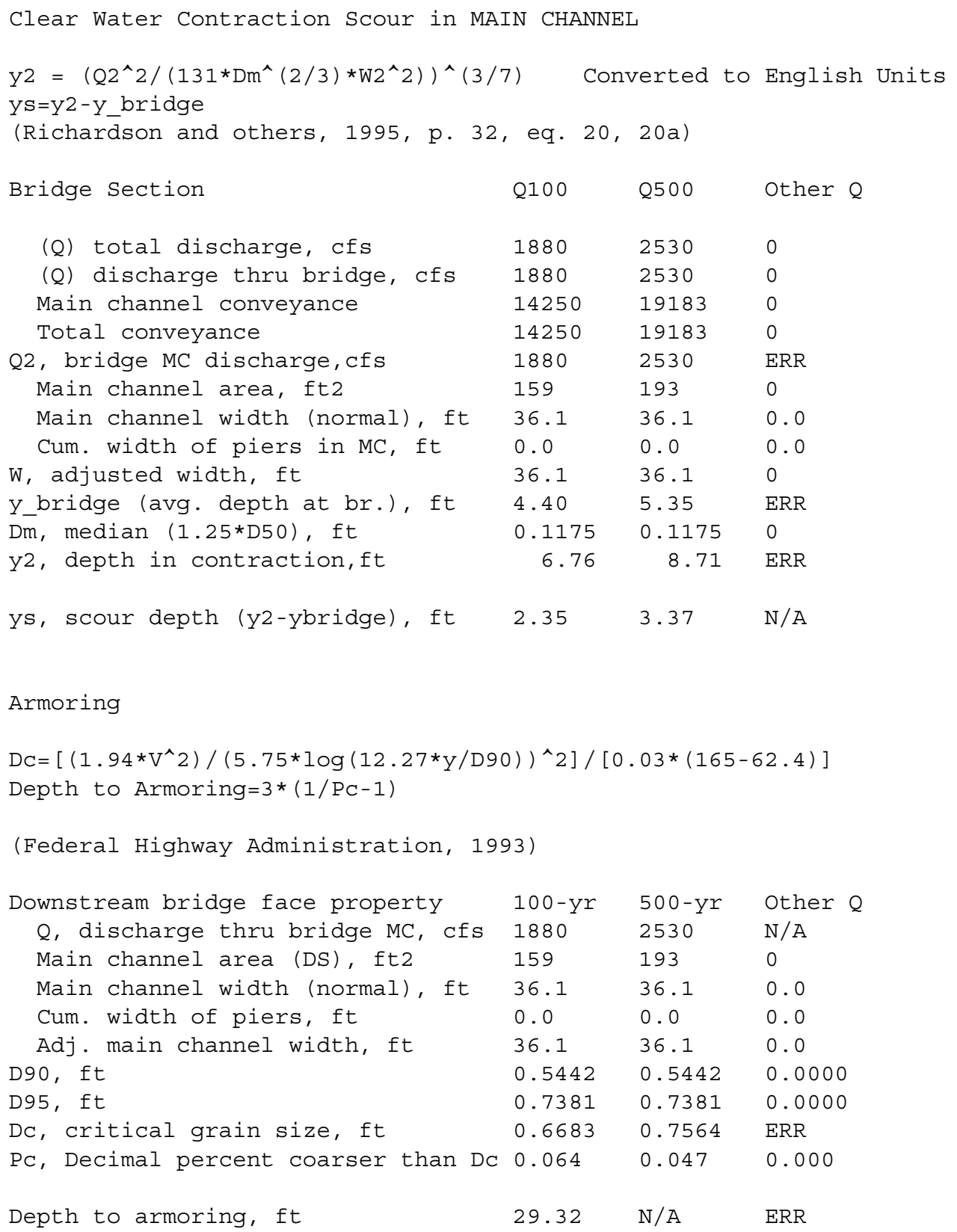


Abutment scour

Froehlich's Abutment Scour

$\mathrm{Ys} / \mathrm{Y} 1=2.27 * \mathrm{~K} 1 * \mathrm{~K} 2 *\left(\mathrm{a}^{\prime} / \mathrm{Y} 1\right) \wedge 0.43 * \mathrm{Fr} 1 \wedge 0.61+1$

(Richardson and others, 1995, p. 48, eq. 28)

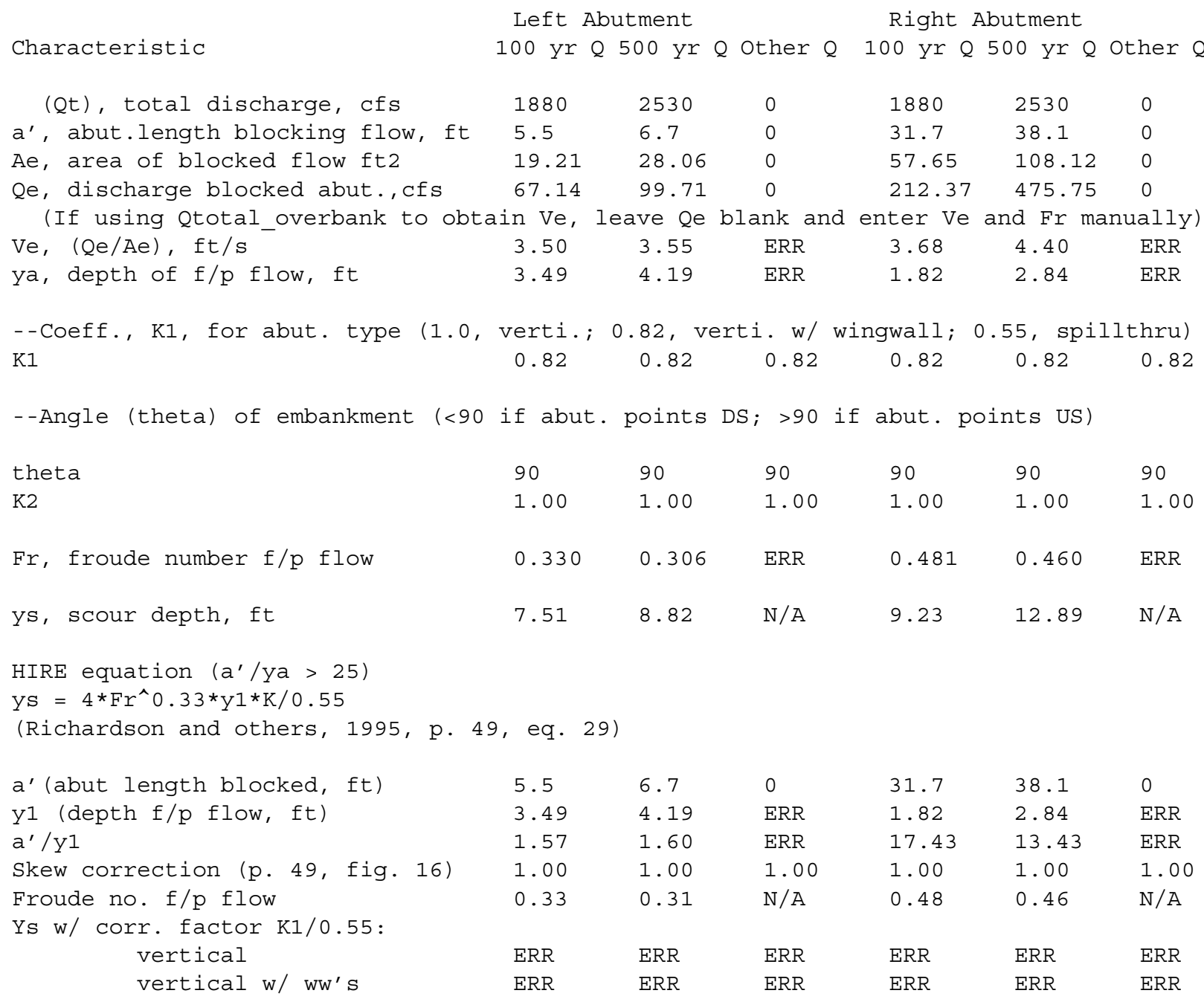




\begin{tabular}{|c|c|c|c|c|c|c|}
\hline spill-through & ERR & ERR & ERR & ERR & ERR & ERR \\
\hline \multicolumn{7}{|l|}{ Abutment riprap Sizing } \\
\hline \multirow{2}{*}{\multicolumn{7}{|c|}{$\begin{array}{l}\text { Isbash Relationship } \\
\mathrm{D} 50=\mathrm{Y}^{\star} \mathrm{K} * \mathrm{Fr} \mathrm{F}^{\wedge} /(\mathrm{Ss}-1) \text { and } \mathrm{D} 50=\mathrm{Y}^{*} \mathrm{~K} *\left(\mathrm{Fr} r^{\wedge} 2\right)^{\wedge} 0.14 /(\mathrm{Ss}-1) \\
\text { (Richardson and others, 1995, p112, eq. 81,82) }\end{array}$}} \\
\hline & & & & & & \\
\hline Characteristic & Q100 & Q500 & Other $Q$ & Q100 & Q500 & Other $Q$ \\
\hline Fr, Froude Number & 1 & 1 & 0 & 1 & 1 & 0 \\
\hline$y$, depth of flow in bridge, ft & 4.40 & 5.35 & 0.00 & 4.40 & 5.35 & 0.00 \\
\hline \multicolumn{7}{|c|}{ Median stone Diameter for riprap at: left abutment } \\
\hline Fr $<=0.8$ (vertical abut.) & ERR & ERR & 0.00 & ERR & ERR & 0.00 \\
\hline Fr>0.8 (vertical abut.) & 1.84 & 2.24 & $\mathrm{ERR}$ & 1.84 & 2.24 & $\mathrm{ERR}$ \\
\hline
\end{tabular}

